\title{
New species and new records of cercosporoid hyphomycetes from Cuba and Venezuela (Part 1)
}

\author{
Braun $\mathbf{U}^{1 *}$ and Urtiaga $\mathbf{R}^{2}$ \\ ${ }^{1}$ Martin-Luther-Universität, Institut für Biologie, Bereich Geobotanik und Botanischer Garten, Herbarium, Neuwerk 21, \\ 06099 Halle (Saale), Germany \\ ${ }^{2}$ Apartado 546, Barquisimeto, Lara, Venezuela.
}

Braun U, Urtiaga R 2012 - New species and new records of cercosporoid hyphomycetes from Cuba and Venezuela (Part 1). Mycosphere 3(3), 301-329, Doi 10.5943/mycosphere/3/3/5

Numerous cercosporoid leaf-spotting hyphomycetes have been continuously collected in Venezuela and several new species and records have been published. Additional specimens, including various collections made between 1966 and 1970 in Cuba and Venezuela, are treated in this paper. The latter material is now housed at K (previously deposited at IMI as "Cercospora sp."). Venezuelan collections made between about 1990 and 2012 (most of them since 2006) are now deposited at HAL. Several species are new to Venezuela, some new host plants are included, and the following new species and new varieties are introduced: Cercospora hadroanthi, Passalora emmeorhizae, $P$. melochiae, Pseudocercospora andirae, $P$. cordiae-alliodorae, $P$. cordiigena, $P$. crescentiae, $P$. gonolobicola, P. jahnii var. amaculata, P. pehriicola, P. rauvolfiae-tetraphyllae, $P$. trichophila var. punctata, Zasmidium asclepiadis. The new combinations Pseudocercospora trichophila var. solaniasperi and Zasmidium gongronematis are proposed.

Key words - Ascomycota - Cercospora - Mycosphaerellaceae - Pseudocercospora - South America

\section{Article Information}

Received 5 April 2012

Accepted 26 April 2012

Published online 13 May 2012

*Corresponding author: U. Braun - e-mail - uwe.braun@ botanik.uni-halle.de

\section{Introduction}

Cercosporoid fungi are anamorphic ascomycetes [Ascomycota, Pezizomycotina, Dothideomycetidae, Capnodiales, Mycosphaerellaceae (Schoch et al. 2006)] and represent one of the largest and most diverse groups of hyphomycetes causing a wide range of diseases of wild as well as numerous cultivated plants. Most of them were previously assigned to a single genus, Cercospora Fresen., which was later variously split into smaller units (e.g., Deighton 1967, 1973, 1974, 1976, 1979, Braun 1993). Several of the segregated genera gained wide acceptance, e.g. Pseudocercospora Speg., whereas the circumscription and application of other genera, e.g. Passalora Fr., remains debatable up to now. Recent molecular sequence analyses, based on increasing data sets and a broader sampling, indicate that generic delimitations within cercosporoid genera are not yet fully perceived and far from being finally established. In the present paper we follow generic concepts outlined in Crous \& Braun (2003).

Cercosporoid hyphomycetes are widespread, almost cosmopolitan fungi with an exceptional diversity in tropical and subtropical regions. Venezuela is a tropical country with a great biodiversity of vascular plant, and accordingly a similarly high diversity of foliicolous fungi. The exploration of this fungal group is, however, far from being complete, i.e., the cercosporoid hyphomycetes from Venezuela are insufficiently known. A first 
contribution to the knowledge of cercosporoid fungi of Venezuela was published by Chupp (1934), and descriptions and records from this work were also used for his monograph of Cercospora (Chupp 1954). Pons (1984, 1988, 1993, 2004, 2007) and García et al. (1996) added further Venezuelan records of cercosporoids and a few new taxa. These data were also used for the preparation of the annotated world checklist of Cercospora species published by Crous \& Braun (2003), which is, therefore, also an important reference list for this fungal group in Venezuela. The second author of the present paper has collected cercosporoid anamorphs since about 1966. Early collections from Cuba and Venezuela were deposited at IMI as Cercospora sp. (recently completely transferred to K). A first set out of these specimens has been sent on loan to the first author to be determined and for further treatment. Venezuelan collections made between about 1990 and 2012 (most of them since 2006) have been directly sent to the first author and are now deposited at HAL. First results of examinations of the collections concerned have already been published by Braun \& Urtiaga (2008) and Braun et al. (2010). Additional results, including new species and new varieties, new records for Venezuela and new host species, are included in the present publication, which will be continued as numerous additional collections have not yet been examined.

\section{Methods}

Sporulating structures were mounted in distilled water without any staining, and examined using oil immersion (bright field and phase contrast), with standard light microscopy (Olympus BX 50, Hamburg, Germany). Thirty measurements (× 1000 magnification) of conidia and other structures were made, with the extremes given in parentheses.

\section{Results and discussion}

New records of cercosporoid hyphomycetes from Cuba and Venezuela and descriptions of new species and new varieties are listed in alphabetical order by genus and species. Discussion and comments are added to each taxon.
Cercospora apii Fresen. s. lat. (C. apii complex, sensu Crous \& Braun 2003)

Material examined - VENEZUELA, Lara, Barquisimeto, on leaves of Plumeria rubra L. (Apocynaceae), Sep. 2010, R. Urtiaga 398 (HAL 2491 F); 1.c., on leaves of Spondias mombin L. (Anacardiaceae), Dec. 2011, R. Urtiaga 457 (HAL 2470 F).

Notes - The collection on Plumeria rubra is a sparse sample with little fructification (stromata intraepidermal, brown, 10$50 \mu \mathrm{m}$ diam., conidiophores fasciculate, 4-7 $\mu \mathrm{m}$ wide, conidiogenous loci 2.5-3.5 $\mu \mathrm{m}$ diam., conidia acicular, colourless, 3-4 $\mu \mathrm{m}$ wide). A specific Cercospora on Plumeria spp. has not been described. The Cercospora on Plumeria rubra is associated with an Asteromella state (pycnidia 30-75 $\mu \mathrm{m}$ diam., with an irregular terminal porus, conidia bacilliform, $2-4 \times 0.8$ $1.2 \mu \mathrm{m})$. There is no specific Cercospora decribed on Spondias and this specimen belongs to the morphological $C$. apii complex. C. verniciferae Chupp \& Viégas on Rhus vernicifera DC. in Brazil coincides morphologically with the fungus on Spondias.

\section{Cercospora beticola Sacc.}

Material examined - VENEZUELA, Lara, Barquisimeto, market, on leaves of Beta vulgaris var. cicla L. (Chenopodiaceae), Jan. 2011, R. Urtiaga 430 (HAL 2481 F).

Notes - Known from Venezuela (Crous \& Braun 2003).

Cercospora brachiata Ellis \& Everh.

Material examined - VENEZUELA, Miranda, Carabobo, on leaves of Amaranthus viridis L. (Amaranthaceae), Apr. 2011, R. Urtiaga 435 (HAL $2482 \mathrm{~F}$ ).

Known from Venezuela (Crous \& Braun 2003).

Cercospora coffeicola Berk. \& Cooke

Material examined - VENEZUELA, Lara, Sanare, Sabana Redonda Arriba, on leaves of Coffea arabica L. (Rubiaceae), Sep. 2010, R. Urtiaga 423 (HAL 2495 F).

Notes - Known from Venezuela (Crous \& Braun 2003).

Cercospora cyperigena U. Braun \& Crous 
Material examined - VENEZUELA, Lara, Barquisimeto, on leaves of Cyperus rotundifolius L. (Cyperaceae), Nov. 2010, R. Urtiaga 427 (HAL 2472 F); 1.c., May 2011, R. Urtiaga 441 (HAL $2471 \mathrm{~F})$.

Notes - This species, hitherto only known from the type collection, was described from Africa (Tanzania), on Cyperus sp. (Crous \& Braun 2003: 151). This species is new to Venezuela and was found on a new host. The current material agrees perfectly with the type material. The conidiophores are very short, 5$15 \times 3-5 \mu \mathrm{m}, 0(-1)$-septate, densely fasciculate, and emerge through stomata. The conidia are long and narrow, 1.5-2.5 $\mu \mathrm{m}$, and scars and hila are small, $1-2 \mu \mathrm{m}$ diam.

Cercospora hadroanthi U. Braun \& Urtiaga, sp. nov. Fig. 1

MycoBank, MB 800018.

Etymology - epithet derived from the host genus, Hadroanthus.

Cercosporae tabebuiae-impetiginosae similis, sed laesionibus distinctis, stromatibus distincte minoribus, $10-50 \mu \mathrm{m}$ diam., conidiophoris longioribus, ad $200 \mu \mathrm{m}$, cicatricibus conspicuis et conidiis longioribus, ad $100 \mu \mathrm{m}$.

Leaf spots large, amphigenous, subcircular to irregular, up to $25 \mathrm{~mm}$ diam., grey to greyish white, with narrow dark brown margin. Caespituli amphigenous, punctiform, dark brown. Mycelium internal; stromata substomatal, 10-50 $\mu \mathrm{m}$ diam., brown, cells $2-6 \mu \mathrm{m}$ diam. Conidiophores in small to usually moderately large, divergent to moderately dense fascicles (5-30), arising from stromata, erect, straight, subcylindrical to moderately geniculate, unbranched, 20-90 $\mu \mathrm{m}$ long and 2.5-4 $\mu \mathrm{m}$ wide, medium brown throughout or tips somewhat paler, wall thin to slightly thickened, smooth, pluriseptate; conidiogenous cells integrated, terminal and intercalary, 10$25 \mu \mathrm{m}$ long, almost straight to distinctly geniculate, with 1-6 conspicuous conidiogenous loci (scars), circular in front view, brown, 1.5-3.5 $\mu \mathrm{m}$ diam., thickened and darkened. Conidia formed singly, long conidia acicular to obclavate-oblong, short conidia fusiform-subcylindrical, 20-90 × 2.5-4 $\mu \mathrm{m}$, usually 3-8-septate, colourless to faintly greenish, smooth, apex acute or subacute, base truncate to usually short obconically truncate, basal hilum 1-3 $\mu \mathrm{m}$ diam., thickened and darkened.

Material examined - CUBA, Bayamo, on leaves of Hadroanthus serratifolius (Vahl) S.O. Grose [ $\equiv$ Tabebuia serratifolia (Vahl) G. Nicholson] (Bignoniaceae), 28 Sep. 1967, R. Urtiaga (IMI 129442b = K(M) 173059), holotype).

Notes - Hadroanthus is not yet known as a host genus of Cercospora species, but several species of the closely related genus Tabebuia have been recorded as a host. Tabebuia sp. has been listed as host of $C$. apii s. lat. (Crous \& Braun 2003). These authors recommended to assign Cercospora collections on hosts of new families, genera or species, which are morphologically indistinguishable from C. apii, to $C$. apii s. lat. (=C. apii complex) since specialized as well as plurivorous taxa are involved in this complex. In such cases, the taxonomy can only be elucidated on the base of cultures and molecular sequence analyses. True collections of $C$. apii s. str. as well as s. lat. are characterized by having acicular conidia with truncate base. However, C. hadroanthi is easily distinguishable from this complex by having conidia with obconically truncate base. In this respect, $C$. hadroanthi resembles $C$. tabebuiaeimpetiginosae Inácio \& Dianese (Inácio \& Dianese 1998), described from Brazil on Hadroanthus impetiginosus (Mart. ex DC.) Mattos ( $\equiv$ Tabebuia impetiginosa (Mart. ex DC.) Standl.), but the latter species is easily distinguishable by its very large stromata, up to $107 \mu \mathrm{m}$ diam., rather short conidiophores, up to $60 \mu \mathrm{m}$, in large, dense fascicles, rather inconspicuous conidiogenous loci and shorter conidia. Tabebuia spp. have also been recorded as hosts of $C$. tecomae Viégas \& Chupp, described on Tecoma sp. from Brazil (Viégas 1945, Chupp 1954, Crous \& Braun 2003). The latter species is, however, part of the C. apii complex with acicular conidia (base truncate) and differs additionally in having broader conidiophores $(4-6 \mu \mathrm{m})$ and much shorter conidia (usually $25-50 \mu \mathrm{m}$ long).

\section{Cercospora lactucae-sativae Sawada}

Material examined - VENEZUELA, Lara, Barquisimeto, on leaves of Lactuca sativ L. (Asteraceae), Jan. 2011, R. Urtiaga 433 (HAL $2480 \mathrm{~F})$. 


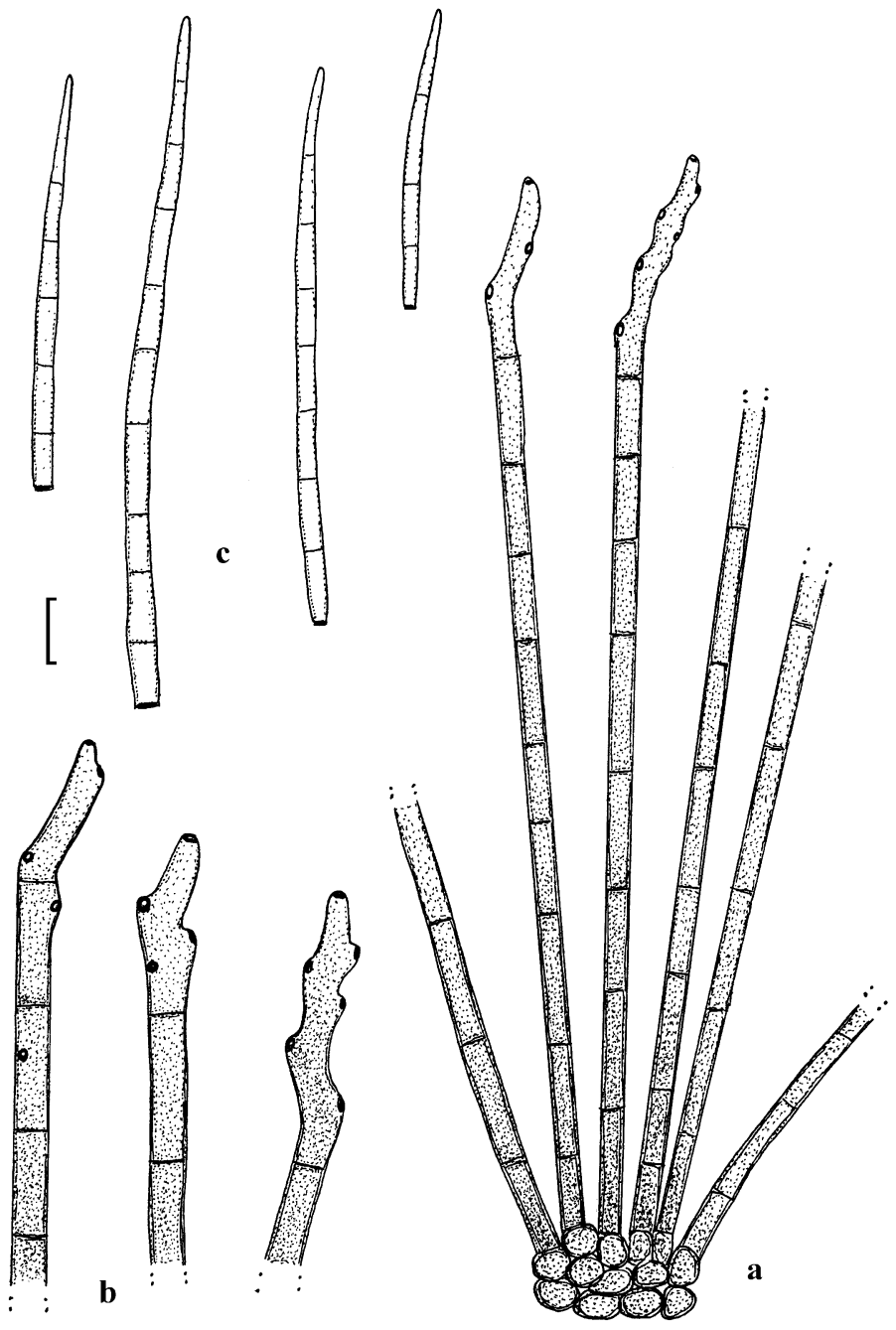

Fig. 1 - Cercospora hadroanthi. Based on type material. a Conidiophore fascicle. b Conidiophores. c Conidia. - Bar $=10 \mu \mathrm{m}$.

Notes - Known from Venezuela (Crous $\&$ Braun 2003).

\section{Cercospora mikaniicola F. Stevens}

Material examined - VENEZUELA, Lara, Sanare, Sabana Redonda Arriba, on leaves of Mikania sp. (Asteraceae), Sep. 2010, R. Urtiaga 402 (HAL 2493 F).

Notes - New to Venezuela (not listed in Crous \& Braun 2003).

Passalora capsicicola (Vassiljevsky) U. Braun \& F. Freire

$\equiv$ Cercospora capsicicola Vassiljevsky.

$\equiv$ Phaeoramularia capsicicola (Vassiljevsky) Deighton.

Material examined - VENEZUELA, Lara, Barquisimeto, El Trompillo, on leaves of Capsicum annuum L. [= C. frutescens L.]
(Solanaceae), Jun. 2000, R. Urtiaga (HAL 2468 F).

Notes - New to Venezuela (not listed in Crous \& Braun 2003).

Passalora emmeorhizae U. Braun \& Urtiaga, sp. nov.

Fig. 2

MycoBank, MB 800006.

Etymology - epithet derived from the host genus, Emmeorhiza.

Differt a Passalora cephalanthi et a P. oldenlandiae conidiis valde brevioribus et latioribus.

Leaf spots almost indistinct, or diffuse to subcircular-irregular, yellowish, olivaceous to brownish, about 2-8 $\mathrm{mm}$ diam., margin indefinite. Caespituli amphigenous, but mainly hypophyllous, punctiform to subeffuse, olivaceous-brown to medium brown. Mycelium 


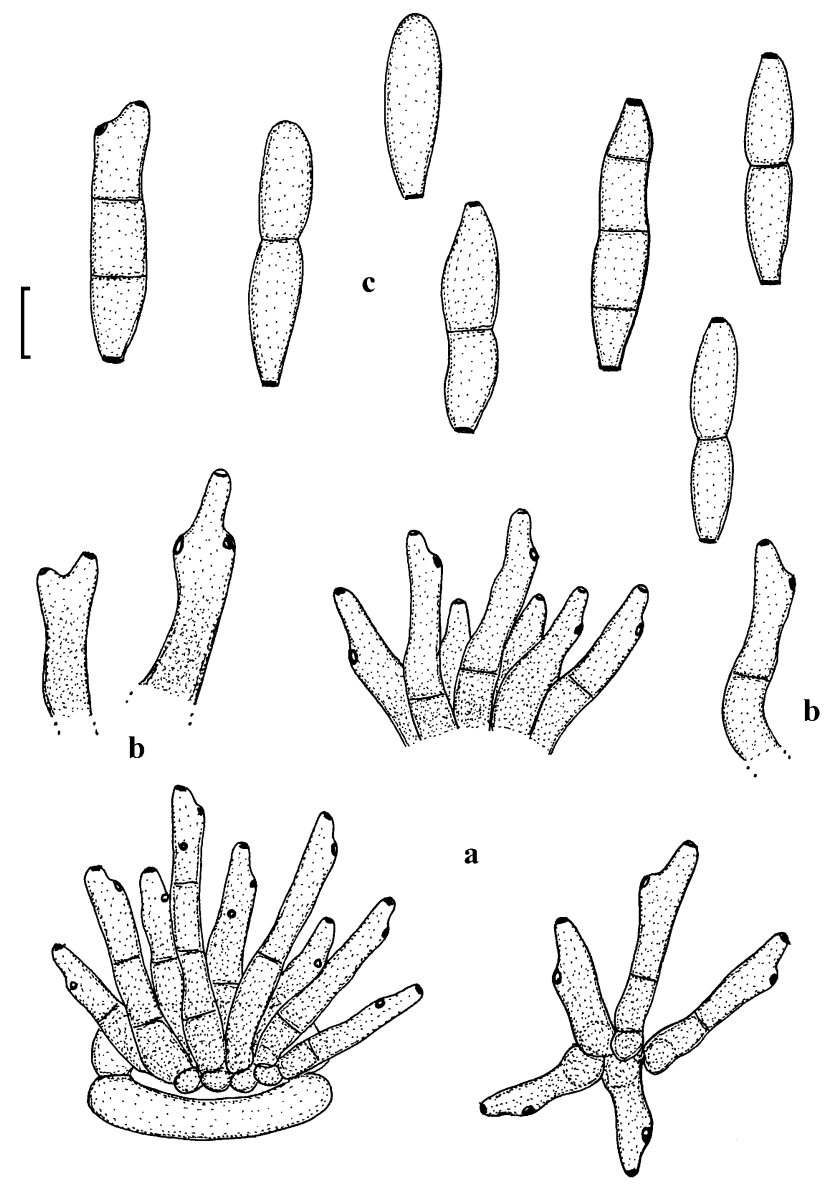

Fig. 2 - Passalora emmeorhizae. Based on type material. a Conidiophore fascicles. b Conidiophores. c Conidia. $-\mathrm{Bar}=10 \mu \mathrm{m}$.

internal; stromata lacking or only with small substomatal hyphal aggregations, 10-30 $\mu \mathrm{m}$ diam., brown. Conidiophores in small, loose to moderately large and dense fascicles, arising from stromata, emerging through stomata, erect, straight, subcylindrical-conical to distinctly geniculate-sinuous, unbranched, 10-60 $\times$ 3-7 $\mu \mathrm{m}, 0-3$-septate, pale olivaceous to olivaceous-brown, medium olivaceous-brown in mass, thin-walled, smooth; conidiogenous cells integrated, terminal or conidiophores reduced to conidiogenous cells, 10-25 $\mu \mathrm{m}$ long, conidiogenous loci (scars) conspicuous, somewhat thickened and darkened, $1.5-2 \mu \mathrm{m}$ diam. Conidia in chains, ellipsoid-ovoid to cylindrical, 15-50 × 4-7 $\mu \mathrm{m}, 0-4$-septate, subhyaline pale olivaceous to olivaceous-brown, thin-walled, smooth, apex rounded to obconically truncate, base obconically truncate, hila 1.5-2 $\mu \mathrm{m}$ wide, slightly thickened and somewhat darkened.

Material examined - VENEZUELA, Lara, Sanare, Sabana Redonda Arriba, on leaves of Emmeorhiza umbellata (Spreng.) K. Schum. (Rubiaceae), May 2009, R. Urtiaga (HAL 2465 $\mathrm{F}$, holotype).

Notes - Passalora emmeorhizae is characterized by lacking superficial mycelium, fasciculate conidiophores and catenate conidia, i.e. it belongs to a group of species previously assigned to the genus Phaeoramularia Munt.Cvetk., which is currently considered a synonym of Passalora. Species of the latter genus on Emmeorhiza are unknown, but three comparable Phaeoramularia-like species have been described from other hosts of the Rubiaceae, viz. P. cephalanthi (Ellis \& Kellerm.) U. Braun $\&$ Crous on Cephalanthus in North America (Chupp 1954, Crous \& Braun 2003), and $P$. oldenlandiae (Hansf.) U. Braun on Borreria and Oldenlandia in Africa (Chupp 1954, Ellis 1976, Crous \& Braun 2003), which are morphologically quite distinct by their very long and narrow, pluriseptate conidia $(10-100 \times 2-$ $4.5 \mu \mathrm{m}$ in $P$. cephalanthi and $22-90 \times 3-5 \mu \mathrm{m}$ in $P$. oldenlandiae), as well as $P$. pseudo- 
capnoides O.L. Pereira \& R.W. Barreto on Mitracarpus hirtus (L.) DC. in Brazil, which differs in having much narrower conidia (2-4 $\mu \mathrm{m}$ wide, Pereira \& Barreto 2005).

Passalora melochiae U. Braun \& Urtiaga, sp. nov. Fig. 3

MycoBank, MB 800007.

Etymology - epithet derived from the host genus, Melochia.

Passalorae meridianae similis, sed fasciculis conidiophorum minoribus, laxioribus, conidiophoris brevioribus, ad $50 \mu \mathrm{m}$, conidiis brevioribus et latioribus, ad $70 \times 6 \mu \mathrm{m}$, saepe 2-7-septatis.

Leaf spots amphigenous, subcircular to somewhat irregular, 1-4 $\mathrm{mm}$ diam., centre ochraceous to greyish white, margin narrow, purple-red to brown, sometimes with diffuse purple halo. Caespituli amphigenous, punctiform, dark brown to blackish, scattered. Mycelium internal; epiphyllous stromata intraepidermal, hypophyllous stromata substomatal, 10-40 $\mu \mathrm{m}$ diam., subcircular, elliptical-oval to somewhat irregular in outline, medium brown, cells $2-6 \mu \mathrm{m}$ diam. Conidiophores in small to moderately large fascicles, arising from stromata, erumpent or emerging through stomata, erect, subcylindrical-conical, straight to slightly geniculate-sinuous, unbranched, 10-50 $\times 2.5-6 \mu \mathrm{m}, 0-2$-septate, thin-walled, smooth, sub-hyaline, pale olivaceous, light brown, medium olivaceous-brown in mass; conidiogenous cells integrated, terminal or conidiophores reduced to conidiogenous cells, 10-35 $\mu \mathrm{m}$ long, coni-diogenous loci (scars) conspicuous, circular, 1-2 $\mu \mathrm{m}$ diam., slightly thickened and darkened. Conidia formed singly or in short chains, cylindrical or subcylindrical, 20-70 × 3-5.5 $\mu \mathrm{m}, \quad(0-) 2-7(-8)$-septate, subhyaline, pale oli-vaceous, olivaceous to light brown in mass, apex obtuse to truncate in catenate conidia, base short obconically truncate, hila 1-2 $\mu \mathrm{m}$ wide, somewhat thickened and darkened.

Material examined - CUBA, Bayamo, on leaves of Melochia pyramidata L. (Malvaceae, Sterculioideae), 8 May 1967, R. Urtiaga (IMI $127445=\mathrm{K}(\mathrm{M})$ 173070, holotype); Bayamo, on leaves of $M$. pyramidata, 29 May 1967, R. Urtiaga (IMI $126779=\mathrm{K}(\mathrm{M})$ 173071).

Notes - Passalora melochiae is charac- terized by forming catenate conidia, i.e. this species belongs to a group of Passalora species previously assigned to Phaeoramularia. $P$. meridiana (Chupp) U. Braun \& Crous on Helicteres spp. (Chupp 1954, Crous \& Braun 2003 ) is the only comparable species on a host of the Sterculioideae (= Sterculiaceae), but differs in having large, dense, coremoid fascicles, much longer conidiophores, up to at least $120 \mu \mathrm{m}$, and much longer and narrower conidia, up to $125 \times 2.5-4 \mu \mathrm{m}$ with up to 11 septa. P. helicteris-viscidae Phengsintham, Chukeatirole, K.D. Hyde \& U. Braun (Phengsintham et al. 2010) is also characterized by catenate conidia, which are, however, quite distinct by being short and narrow, $8-44 \times 1-3$ $\mu \mathrm{m}, 0-4$-septate and hyaline. Other species are Mycovellosiella-like, i.e. with superficial hyphae and solitary conidiophores [Passalora sterculiacearum U. Braun \& Crous (Braun \& Crous 2007), P. dombayae (Crous \& U. Braun) Crous \& U. Braun (Crous \& Braun 2003)], or the conidia are consistently formed singly $[P$. helicteris (Soni, Dadwal \& Jamaluddin) Poonam Srivast. (Soni et al. 1984)].

Pseudocercospora andirae U. Braun \& Urtiaga, sp. nov. Fig. 4

MycoBank, MB 800008.

Etymology - epithet derived from the host genus, Andira.

Pseudocercosporae vataireae similis, sed stromatibus minoribus, $10-50 \mu \mathrm{m}$ diam., conidiophoris laevibus, saepe geniculatis-sinuosis. Differt a P. stevensii ad species Andirae laesionibus plene distinctis, hyphis superficialibus cum conidiophoris solitariis formantibus et conidiophoris valde brevioribus, $10-70(-80)$ $\mu \mathrm{m}$.

Leaf spots amphigenous, conspicuous, subcircular to somewhat angular-irregular, 2$10 \mathrm{~mm}$ diam. or confluent and larger, occasionally somewhat zonate, brown, ranging from pale to medium dark brown, later grayish brown to dingy grey or greyish white, margin indefinite or with a narrow darker marginal line, often with narrow to broad, brown, necrotic halo. Caespituli amphigenous, punctiform to confluent and dense, dark brown to blackish. Mycelium internal and external; superficial hyphae only on the lower leaf surface, branched, straight to sinuous, $1-4 \mu \mathrm{m}$ 


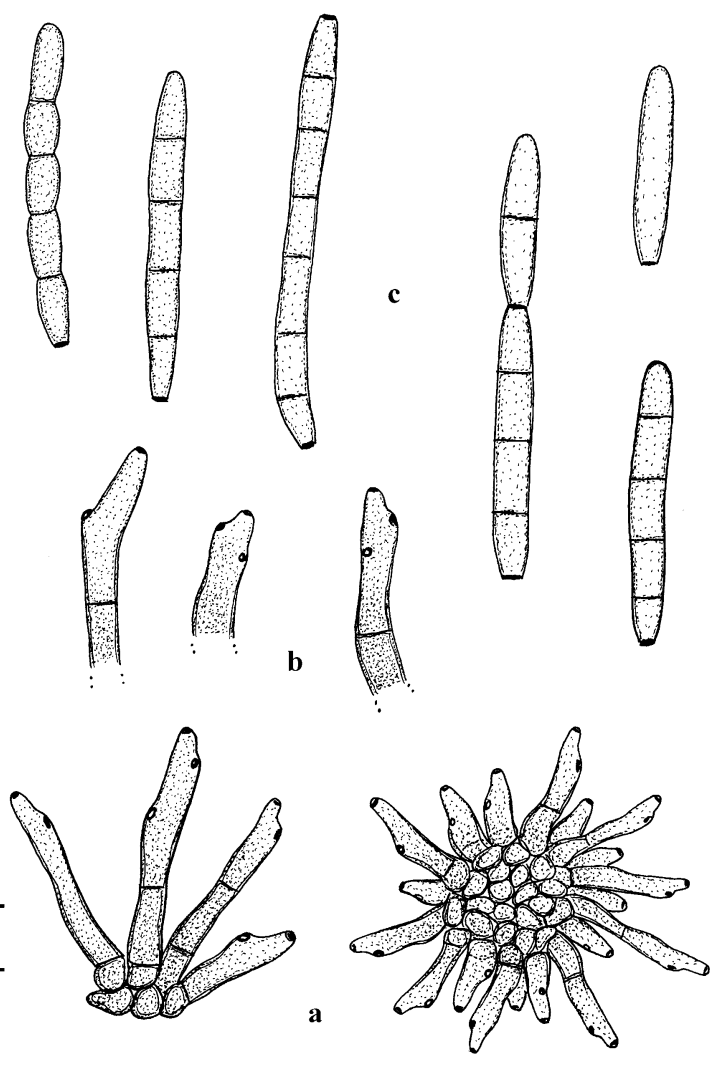

Fig. 3 - Passalora melochiae. Based on type material. a Conidiophore fascicles. b Coni-diophores. c - conidia. - Bar $=10 \mu \mathrm{m}$.

wide, septate, subhyaline to pale olivaceous or olivaceous-brown, thin-walled, smooth; stromata substomatal or intraepidermal, subcircular to elongated or somewhat irregular in outline, medium to dark olivaceous-brown, hypophyllous stromata $10-50 \mu \mathrm{m}$ diam., epiphyllous ones up to $80 \mu \mathrm{m}$ diam., cells $2.5-7$ $\mu \mathrm{m}$ diam. Conidiophores in small to moderately large, loose to dense fascicles, arising from stromata, through stomata or solitary, arising from superficial hyphae, lateral, rarely single conidiophores emerging through stomata, erect, straight, subcylindrical-conical to geniculate-sinuous, simple or occasionally branched, 10-70 $(-80) \times 3-5 \mu \mathrm{m}, 0-5$-septate, pale to medium olivaceous or olivaceousbrown, thin-walled, smooth or almost so; conidiogenous cells integrated, terminal or conidiophores reduced to conidiogenous cells, 10-25 $\mu \mathrm{m}$ long, conidiogenous loci inconspicuous to denticle-like, but always unthickened and not darkened. Conidia formed singly, obclavate-subcylindrical, short conidia occasionally fusiform, $(15-) 25-80 \times(2.5-) 3-$ $5(-6) \mu \mathrm{m},(1-) 3-8$-septate, pale olivaceous to olivaceous-brown, thin-walled, smooth to faintly rough-walled, apex subobtuse, base short obconically truncate, $1-2 \mu \mathrm{m}$ wide, hilum neither thickened nor darkened.

Material examined - VENEZUELA, Lara, Barquisimeto, Bosque Macuto, on leaves of Andira surinamensis (Bondt) Splitg. ex Pulle (Fabaceae), Mar. 2010, R. Urtiaga (HAL 2466 F, holotype); Barquisimeto, Zoo, on leaves of Andira inermis (W. Wright) Kunth ex DC. (Fabaceae), Jan. 2011, R. Urtiaga 432 (HAL $2479 \mathrm{~F}$, paratype).

Notes - Pseudocercospora stevensii (E. Yong) U. Braun \& Crous (Chupp 1954, Crous \& Braun 2003) is known from South America on Andira spp., including A. surinamensis. Type material of this species has been examined (on Andira sp., Puerto Rico, Dos Bocas, below Utuado, 30 Dec. 1913, F.L. Stevens, ILL 6008 and PC). This species is, however, quite distinct from $P$. andirae (leaf spots lacking or only with indistinct small reddish brown spots, mycelium internal, superficial hyphae with solitary conidiophores not formed and conidiophores very long, about 


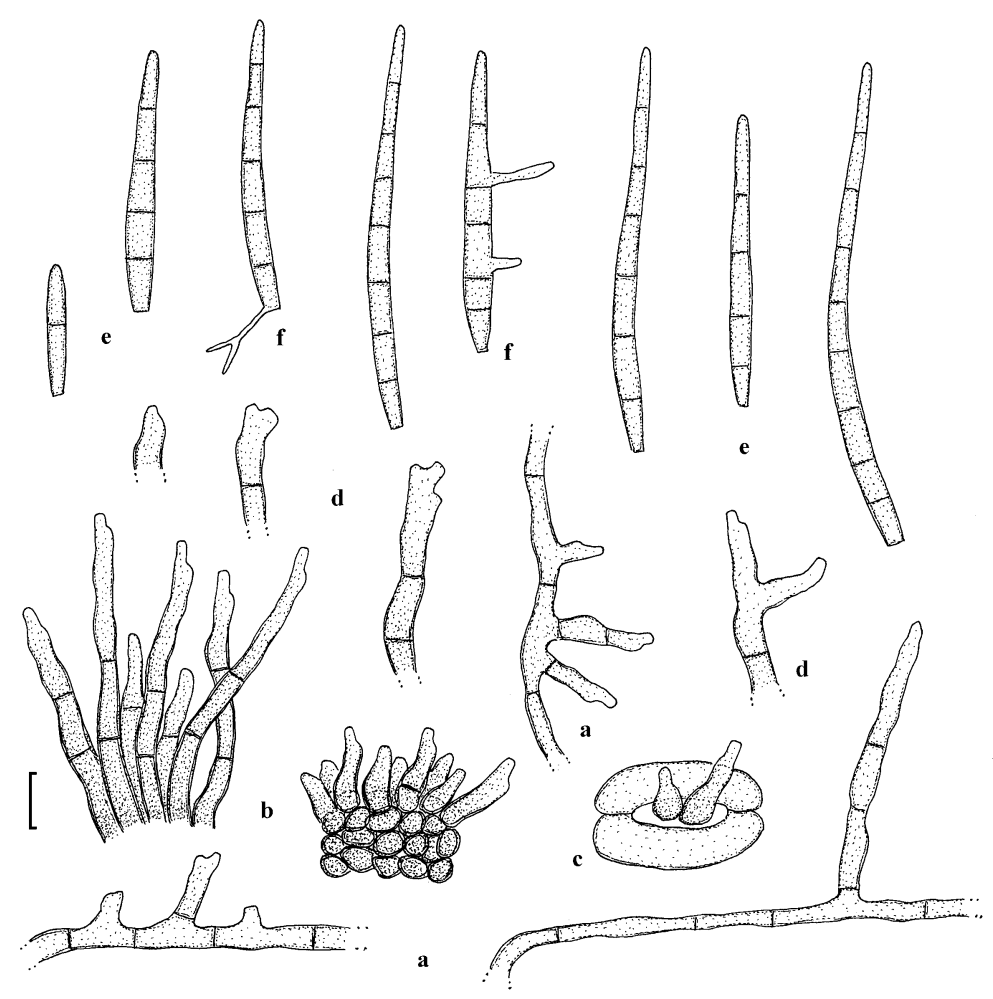

Fig. 4 - Pseudocercospora andirae. Based on type material. a Superficial hyphae with solitary conidiophores. b Conidiophore fascicles. c Conidiophores emerging through a stoma. d Conidiophores. e Conidia. f Germinating conidia - Bar $=10 \mu \mathrm{m}$.

50-200 $\mu \mathrm{m}$, mostly in dense, often almost coremioid fascicles). In phylogenetic analyses, the genus Andira clustered in a basal unresolved position within the aeschynomenoid group (Dalbergieae and Aeschynomeneae, see Doyle et al. 2000). Among Pseudocercospora spp. on hosts of closely as well as distantly allied genera of the Dalbergieae and Aeschynomeneae, there are only few comparable species. P. vataireae (Henn.) U. Braun \& Freire (Braun \& Freire 2002) on Derris spp. in Brazil is morphologically similar by forming solitary conidiophores arising from superficial hyphae, but this species forms much larger stromata, up to $150 \mu \mathrm{m}$ diam., and the conidiophores are usually subcylindrical and straight, i.e. non-geniculate, verruculose towards the tip and often percurrently proliferating. In other species, viz. $P$. dalbergiae (S.H. Sun) J.M. Yen on Dalbergia spp. in Asia (Hsieh \& Goh 1990, Guo et al. 1995), P. pongamiae-pinnatae Raghu Ram \& Mallaiah on Pongamia sp. in India (Raghu Ram \& Mallaiah 1993) and P. pterocarpicola (J.M. Yen) J.M. Yen var. pterocarpicola and var. guzmanii (Tak. Kobay.) U. Braun on Ptero- carpus spp. in Asia and Oceania (Yen \& Lim 1980, Braun et al. 1999, Crous \& Braun 2003), superficial hyphae and solitary conidiophores are lacking. In addition, the conidia in $P$. dalbergiae and $P$. pongamiae-pinnatae are much narrower, 2-3 $\mu \mathrm{m}$, and in $P$. pterocarpicola they are much wider, (4-)5-8(-10) $\mu \mathrm{m}$. The South American P. lonchocarpi (J.A. Stev.) Crous \& M.P.S Câmara (Crous \& Câmara 1998) forms superficial mycelium, but without any solitary conidiophores. Furthermore, the conidiogenous cells are often percurrent and the verruculose conidia of this species are much longer and narrower, (30-) 50-100(-120) × (2-)3-3.5(-4.5) $\mu \mathrm{m}$ (Chupp 1954, Crous \& Câmara 1998).

Pseudocercospora atromarginalis (G.F. Atk.) Deighton

$\equiv$ Cercospora atromarginalis G.F. Atk.

Material examined - VENEZUELA, Lara, Sanare, Sabana Redonda Arriba, on leaves of Solanum nigrum L. (Solanaceae), Jun. 2010, R. Urtiaga 389 (HAL 2497 F).

Notes - New to Venezuela (not listed in Crous \& Braun 2003). 
Pseudocercospora cordiae-alliodorae

Braun \& Urtiaga, sp. nov. Fig. 5

MycoBank, MB 800009.

Etymology - epithet derived from the host species, Cordia alliodora.

Pseudocercosporae cordiicolae similis, sed conidiis valde brevioribus et latioribus, 12 $40 \times 2-4 \mu \mathrm{m}$, modo 1-4-septatis.

Leaf spots lacking or only with diffuse greyish brown discolorations, rather inconspicuous. Colonies hypophyllous, effuse, olivaceous-brown, but rather inconspicuous. Mycelium internal and external, hyphae superficial, emerging through stomata, also climbing leaf hairs, branched, sometimes anastomosing, 1-4 $\mu \mathrm{m}$ wide, septate, subhyaline to pale olivaceous or olivaceous-brown, thin-walled, smooth; stromata lacking. Conidiophores solitary, arising from superficial hyphae, lateral, erect, straight, subcylindrical to conical or somewhat geniculate or curved-sinuous, unbranched, 4-25 × 2-4 $\mu \mathrm{m}, 0(-1)$-septate, subhyaline, pale olivaceous to olivaceous-brown, thin-walled, smooth; conidiophores usually reduced to conidiogenous cells, conidiogenous loci inconspicuous. Conidia formed singly, obclavate-cylindrical, short conidia sometimes ellipsoid-fusiform, $12-40 \times 2-4 \mu \mathrm{m}, 1-4-$ septate, subhyaline to pale olivaceous or olivaceous-brown, thin-walled, smooth, apex obtuse to subacute, base short obconically truncate, $1-1.5(-2) \mu \mathrm{m}$ wide, hila unthickened, not darkened.

Material examined - VENEZUELA, Lara, Barquisimeto, zoological garden, on leaves of Cordia alliodora (Ruiz \& Pav.) Oken (Boraginaceae), May 2011, R. Urtiaga (HAL $2464 \mathrm{~F}$, holotype).

Notes - The Asian Pseudocercospora cordiicola (J.M. Yen) J.M. Yen (Yen \& Lim 1980 ) is a comparable species, but differs from the new South American P. cordiae-alliodorae in having much longer and narrower conidia, about $80-125 \times 1.5-2.5 \mu \mathrm{m}$, with $4-8$ septa.

\section{Pseudocercospora cordiigena U. Braun \& Urtiaga, sp. nov. Fig. 6 \\ MycoBank, MB 800010. \\ Etymology - epithet derived from the} host genus, Cordia. Pseudocercosporae cordianae similis, sed conidiophoris latioribus (3-6 $\mu \mathrm{m})$ et conidiis latioribus, 4-8 $\mu \mathrm{m}, 0-7-$ septatis.

Leaf spots amphigenous, angular-irregular, often vein-limited, darker brown on the upper leaf surface, paler brown below, 1-8 $\mathrm{mm}$ diam. or confluent and larger, margin not differentiated, but often with yellowish to ochraceous halo. Caespituli amphigenous, usually epiphyllous, rather inconspicuous. Mycelium internal; stromata small to well developed, 15-45 $\mu \mathrm{m}$, intraepidermal on the upper side, hypophyllous stromata also substomatal, subcircular to somewhat irregular in outline, medium to dark olivaceous-brown, cells circular to angular in outline, $3-8 \mu \mathrm{m}$ diam. Conidiophores in small to moderately large fascicles, arising from stromata, erect, straight, unbranched to somewhat curved or slightly geniculate-sinuous, almost cylindrical, somewhat attenuated towards the tip or subclavate, $8-25 \times 3-6 \mu \mathrm{m}$, up to $55 \mu \mathrm{m}$ long with still attached young conidia, pale to medium olivaceous-brown throughout or paler towards the tip, subhyaline to very pale olivaceous, young conidiophores sometimes subhyaline, wall thin to slightly thickened (up to $0.75 \mu \mathrm{m}$ ), smooth; conidiogenous cells integrated, terminal or conidiophores one-celled, i.e. reduced to conidiogenous cells, 8-20 $\mu \mathrm{m}$ long, conidiogenous loci inconspicuous. Conidia formed singly, obclavate, young conidia subcylindrical, broadly fusiform or subclavate, often long attached at conidiogenous cells, 25-70(90) $\times 4-8 \mu \mathrm{m}, 0-7$-septate, pale to medium olivaceous or olivaceous-brown, wall up to $0.75 \mu \mathrm{m}$ wide, smooth, apex obtuse, rounded, base short obconically truncate, 2-3.5 $\mu \mathrm{m}$ wide, hila neither thickened nor darkened.

Material examined - CUBA, Bayamo, on leaves of Cordia dentata Poir. (Boraginaceae), 21 Jan. 1967, R. Urtiaga (IMI $124810=\mathrm{K}(\mathrm{M})$ 173055, holotype).

Notes - Crous et al. (2000) described Pseudocercospora cordiana Crous \& Bench. from Brazil on Cordia goeldiana Huber. This species is superficially similar, but has narrower conidiophores, only $2.5-4 \mu \mathrm{m}$ wide, and narrower conidia, (30-)40-46 $\mu \mathrm{m}$ long and only 2-3 $\mu \mathrm{m}$ wide and 1-3(-5)-septate. Two other Pseudocercospora species described on Cordia spp. are morphologically distinct. $P$. cordiae Kamal \& R.P. Singh (Kamal \& Singh 1980) differs in having longer, pluriseptate 


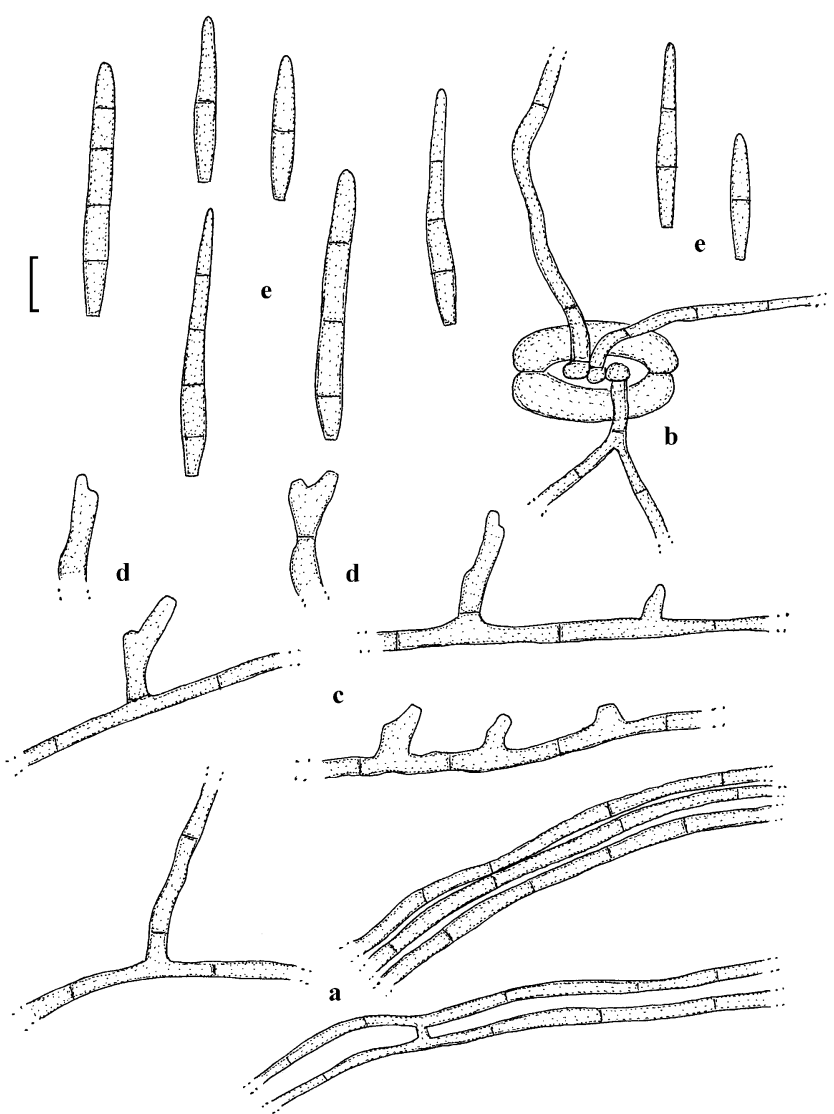

Fig. 5 - Pseudocercospora cordiae-alliodorae. Based on type material. a Superficial hyphae. b Hyphae emerging through a stoma. c Superficial hyphae with solitary conidiophores. d Conidiophores. e Conidia $-\mathrm{Bar}=10 \mu \mathrm{m}$.

conidiophores, 54-90 $\mu \mathrm{m}$, and smaller conidia,21.5-30 $\times$ 3.5-4.5 $\mu \mathrm{m}$, and $P$. cordiicola (J.M. Yen) J. M. Yen (Yen \& Lim 1980) is characterized by lacking stromata, superficial hyphae with solitary conidiophores and very long and narrow conidia, 80-125 $\times$ $1.5-2.5 \mu \mathrm{m}$.

Pseudocercospora costi (F. Stevens) U. Braun $\&$ Crous

\section{$\equiv$ Cercospora costi F. Stevens.}

Material examined - VENEZUELA, Lara, Sanare, Sabana Redonda Arriba, on leaves of Costus sp. (Zingiberaceae), Sep. 2010, R. Urtiaga 424 (HAL 2489 F).

Notes - This species was described from Panama and is known from Venezuela on Costus sp. (Crous \& Braun 2003).

Pseudocercospora crescentiae U. Braun \& Urtiaga, sp. nov. Fig. 7

MycoBank, MB 800011.

Etymology - epithet derived from the host genus, Crescentia. Pseudocercosporae tabebuiae-roseoalbae valde similis, sed caespitulis epiphyllis et hypophyllis distincte dimorphis, conidiophoris interdum ramosis et conidiis ad basim breviter obconice truncatis.

Leaf spots amphigenous, subcircular to angular-irregular, $1-10 \mathrm{~mm}$ diam., rarely larger, brown, greyish brown, later becoming very pale, grey-brown to greyish white, with narrow brown margin. Caespituli amphiogenous, on the upper leaf surface conspicuously punctiform, dark brown to blackish, on the lower side punctiform to subeffuse. Mycelium internal; epiphyllous stromata large, 30-70 $\mu \mathrm{m}$ diam., intraepidermal, dark olivaceous-brown to brown, cells rounded to angular in outline, 2-7 $\mu \mathrm{m}$ diam., stromata on the lower side lacking or smaller, 10-50 $\mu \mathrm{m}$ diam., mostly substomatal. Conidiophores fasciculate, fascicles dimorphic, on the upper leaf surface always in large, dense, erumpent sporodochial conidiomata, straight to slightly geniculatesinuous, unbranched, subcylindrical-conical, 5$25 \times 2-4.5 \mu \mathrm{m}, 0-1$-septate, on the lower side in smaller, mostly loose fascicles, usually emerging through stomata, erect to decumbent, almost straight, cylindrical to mostly distinctly 


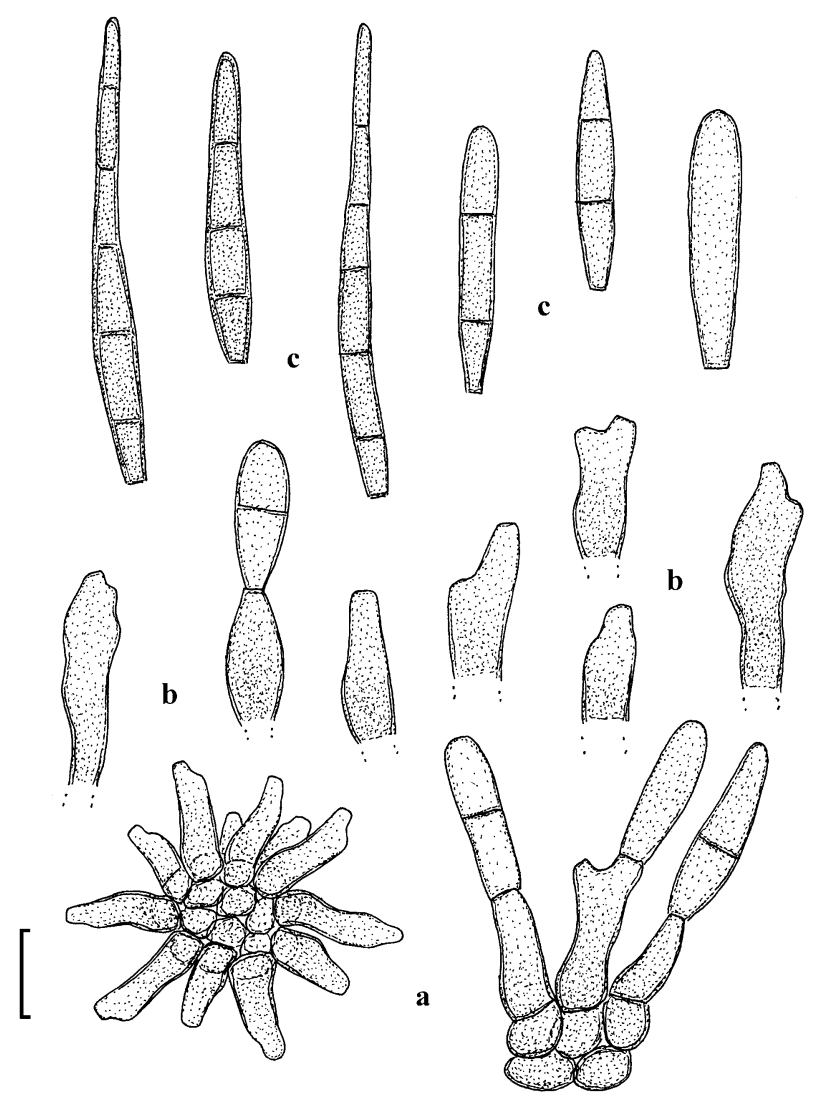

Fig. 6 - Pseudocercospora cordiigena. Based on type material. a Conidiophore fascicles. b Conidiophores. c Conidia. - Bar $=10 \mu \mathrm{m}$.

geniculate-sinuous, simple or often branched, $10-60 \times 2.5-6 \mu \mathrm{m}, 0-4$-septate, pale to somewhat darker olivaceous-brown, thin-walled, smooth or almost so; conidiogenous cells integrated, terminal or occasionally intercalary, 10-30 $\mu \mathrm{m}$ long, conidiogenous loci (scars) inconspicuous. Conidia solitary, obclavatesubcylindrical, short conidia sometimes cylindrical-fusiform, $12-60 \times(1.5-) 2-4(-4.5 \mu \mathrm{m})$, 1-5-septate, subhyaline to pale olivaceous, thin-walled, smooth, apex obtuse to subacute, base short obconically truncate, in short conidia sometimes truncate, hila 1-2 $\mu \mathrm{m}$ diam., neither thickened nor darkened.

Material examined - CUBA, Media Luna, on leaves of Crescentia cujete L. (Bignoniaceae), 12 Jul. 1967, R. Urtiaga 799 (IMI $129036=\mathrm{K}(\mathrm{M})$ 173063); Bayamo, on leaves of Crescentia cujete, 18 Mar. 1968, R. Urtiaga 1210 (IMI $132556=\mathrm{K}(\mathrm{M})$ 173060). VENEZUELA, Sucre State, Cumanacoa, on leaves of Crescentia cujete, 15 Jan. 1971, R. Urtiaga 1345 (IMI 156326 = K(M) 173061, holotype); without locality, on leaves of Crescentia cujete, 23 Jun. 1970, R. Urtiaga 1237 (IMI 149973 =

\section{K(M) 173062).}

Notes - Many Pseudocercospora species have been described on hosts belonging to the Bignoniaceae. $P$. crescentiae differs from all known species in forming distinctly dimorphic caespituli, with obvious differences between epiphyllous and hypophyllous conidiophore fascicles. On the upper leaf surface, the conidiophores form sporodochial conidiomata with large stromata. Numerous Pseudocercospora species on hosts of the Bignoniaceae are quite distinct from $P$. crescentiae by lacking or possessing very small stromata [viz., $P$. arrabidaeae R. Kirschner (Kirschner \& Piepenbring 2006), P. bignoniacearum B.K. Gupta \& Kamal (Gupta \& Kamal 1987), P. brasiliensis U. Braun \& F.O. Freire (Braun \& Freire 2004), P. dolichandrones (Chupp) Deighton (Chupp 1954), P. hansfordii (Chupp) Deighton (Chupp 1954), P. millingtoniae Raghu Ram \& Mallaiah (Raghu Ram \& Mallaiah 1996), P. oroxyligena J.M. Yen, A.K. Kar \& B.K. Das (Yen et al. 1982a), P. pandoreae U. Braun \& C.F. Hill (Braun et al. 2006), P. sordida (Sacc.) Deighton (Chupp 


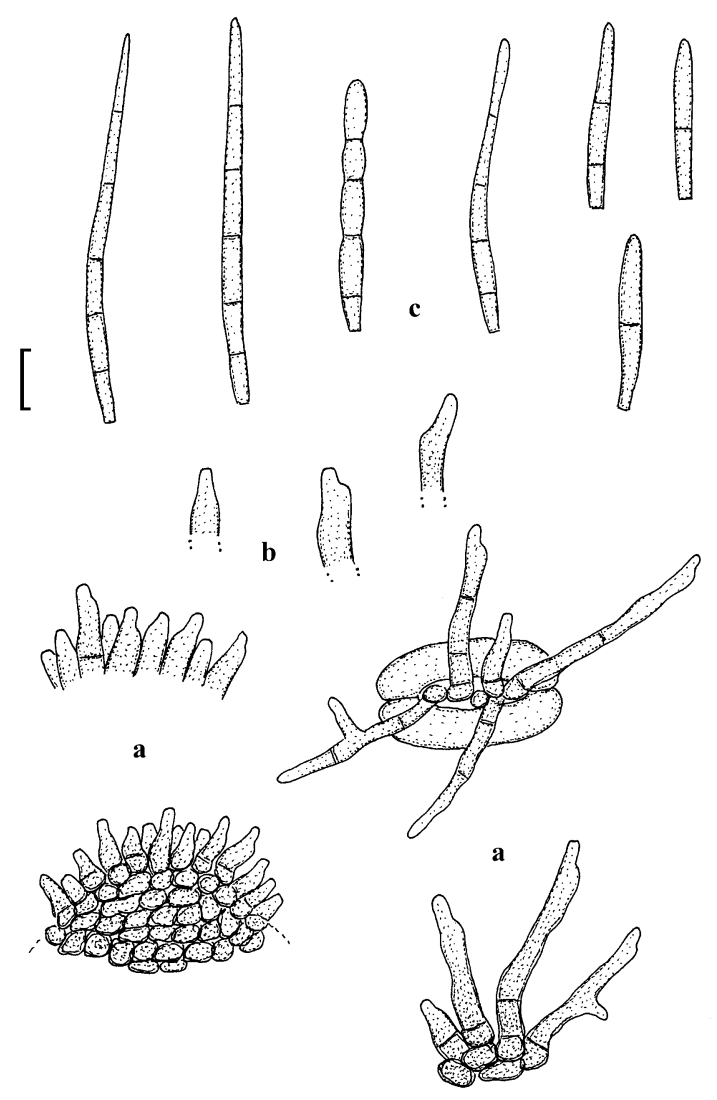

Fig. 7 - Pseudocercospora crescentiae. Based on type material. a Conidiophore fascicles. b Conidiophores. c Conidia. - Bar $=10 \mu \mathrm{m}$.

1954), P. tecomae-heterophyllae (J.M. Yen) Y.L. Guo \& X.J. Liu (Guo \& Hsieh 1995)]. Among species with well-developed stromata, Pseudocercospora crescentiae is close to $P$. jahnii (Syd.) U. Braun \& Crous (Chupp 1954, Crous \& Braun 2003) and P. tabebuiaeroseoalbae Inácio \& Dianese (Inácio \& Dianese 1998). However, the latter two species do not form comparable dimorphic conidiophore fascicles. The unbranched conidiophores always arise from stromata. Other species with larger stromata are easily distinguishable: $P$. catalpigena U. Braun \& Crous (conidia cylindrical; Braun et al. 2003), $P$. catalpicola U. Braun (superficial hyphae with solitary conidiophores developed; Braun 1999), P. stereospermicola Srisk. \& Sivan. (longer conidia, 50-110 $\mu \mathrm{m}$, with up to 10 septa; Sriskantha \& Sivanesan 1980), $P$. tabebuiae-caraibae Inácio \& Dianese (with large lesions, up to $30 \mu \mathrm{m}$ diam., conidiophores 4-6 $\mu \mathrm{m}$ wide, conidia up to $100 \mu \mathrm{m}$ long, with up to eight septa; Inácio \& Dianese 2006), $P$. zeyheriae (Henn.) Dianese, Furlanetto \& L.T.P. Santos (stromata large, 60-240 $\mu \mathrm{m}$ diam., conidia up to $100 \mu \mathrm{m}$ long, with up to 13 septa, superficial hyphae with solitary conidiophores developed; Dianese et al. 1999).

Pseudocercospora cruenta (Sacc.) Deighton

$\equiv$ Cercospora cruenta Sacc. Material examined - VENEZUELA, La-ra, Barquisimeto, on leaves of Vigna ungu-iculata (Fabaceae), Sep. 2010, R. Urtiaga 422 (HAL $2493 \mathrm{~F})$.

Notes - Known from Venezuela (Crous $\&$ Braun 2003). This species is widespread and common on various legumes.

Pseudocercospora durantae N. Pons, U. Braun $\&$ Crous

$\equiv$ Cercospora durantae Chupp \& A.S. Mull., nom. inval.

Material examined - VENEZUELA, Lara, Barquisimeto, on leaves of Duranta erecta L. [= D. repens L.] (Verbenaceae), Jul. 2011, R. Urtiaga 449 (HAL 2477 F).

Notes - Pons et al. (in Crous \& Braun 2003: 168) validated Cercospora durantae. Type material of this species is from Venezuela on Duranta mutisii. D. erecta is known as host 
of this species from Florida, USA. This is the first record on the latter host from Venezuela. Morphological characters of the present material agrees perfectly with the type of this species.

Pseudocercospora gonolobicola U. Braun \& Urtiaga, sp. nov. Fig. 8

MycoBank, MB 800012.

Etymology - epithet derived from the host genus, Gonolobus.

Differt a Cercospora gonolobi hyphis superficialibus cum conidiophoris solitariis, conidiophoris valde brevioribus, 3-25 $\mu \mathrm{m}, 0$ 1(-2)-septatis et conidiis angustioribus, 2-4 $\mu \mathrm{m}$.

Lesions diffuse to angular-irregular, up to $20 \mathrm{~mm}$ diam., sometimes vein-limited, yellowish, olivaceous to brownish, margin indefinite. Colonies amphigenous, epiphyllous caespituli punctiform, dark brown, scattered, hypophyllous colonies effuse to aggregated, dingy greyish to olivaceous-brown. Mycelium internal and external, superficial hyphae mainly hypophyllous, emerging through stomata, sometimes forming ropes, sparingly branched, 1.5-4 $\mu \mathrm{m}$ wide, subhyaline to pale olivaceous, later olivaceous-brown, septate, thin-walled, smooth; stromata mainly epiphyllous, intraepidermal, 15-50 $\mu \mathrm{m}$ diam., dark brown, composed of medium brown cells, subcircular to somewhat angular-irregular in outline, 2.5-7 $\mu \mathrm{m}$ diam. Conidiophores in small to moderately large fascicles, arising from stromata, erumpent, or conidiophores solitary, arising from superficial hyphae, lateral, erect, straight, subcylindrical-conical to moderately geniculate-sinuous, unbranched, 3-25 × 2-5 $\mu \mathrm{m}, 0$ $1(-2)$-septate, subhyaline to pale olivaceous or olivaceous-brown, thin-walled, smooth; conidiogenous cells integrated, terminal or conidiophores often aseptate, i.e. reduced to conidiogenous cells, 2-20 $\mu \mathrm{m}$ long, conidiogenous loci inconspicuous. Conidia formed singly, narrowly obclavate-cylindrical, short conidia sometimes ellipsoid-fusiform, 15-70 × 2-4 $\mu \mathrm{m},(1-) 2-6(-7)$-septate, subhyaline to pale olivaceous, thin-walled, smooth, apex subacute or subobtuse, base short obconically truncate, (1-)1.5-2 $\mu \mathrm{m}$ wide, hila neither thickened nor darkened.

Material examined - VENEZUELA, without locality, on leaves of Gonolobus rostratus (Vahl) R. Br. ex Schult. (Asclepiadaceae), 14 Mar. 1969, R. Urtiaga 247 (IMI $139317=\mathrm{K}(\mathrm{M})$ 173064, holotype).

Notes - Cercospora gonolobi W.W. Ray has been described from North America (USA, Oklahoma) on Gonolobus laevis Michx. (三 Cynanchum leave (Michx.) Pers.).

The generic affinity of this species is still unresolved, but due to pigmented conidia (Chupp 1954) this species undoubtedly does not belong to Cercospora s. str. In any case, $C$. gonolobi is morphologically quite distinct by lacking superficial mycelium and by its much longer, pluriseptate conidia (up to $80 \mu \mathrm{m}$ ) which are also wider $(4-5 \mu \mathrm{m})$. There is no comparable species among numerous Pseudocercospora species described from hosts of the Asclepiadaceae. Guo \& Hsieh (1995) recorded, described and illustrated $P$. marsdeniae (Hansf.) Deighton from China on Dregea sinensis Hemsl., characterized by having fasciculate conidiophores arising from stromata as well as solitary conidiophores arising from superficial hyphae, but conidiophores and conidia are much longer and above all broader $(3-6.5 \mu \mathrm{m})$ than those of $P$. gonolobicola. However, the Chinese collection on Dregea sinensis is undoubtedly not conspecific with the African P. marsdeniae, which does not form any superficial hyphae (Chupp 1954, Deighton 1976), and probably represents a separate undescribed species.

Pseudocercospora jahnii (Syd.) U. Braun \& Crous var.jahnii Fig. 9

$\equiv$ Cercospora jahnii Syd.

= Cercoseptoria tabebuiicola Kamal, Narayan \& R.P. Verma.

= Pseudocercospora tabebuiae-roseoalbae Inácio \& Dianese.

Leaf spots amphigenous, subcircular to angular-irregular, 2-15 mm diam., pale or dull brown, greyish brown, finally greyish white, with darker margin, brown to reddish brown. Caespituli hypophyllous, rarely amphigenous, delicately to distinctly punctiform, scattered to aggregated, blackish brown, greyish black. Mycelium internal and external; superficial hyphae branched, septate, thin-walled, smooth, 1.5-3 $\mu \mathrm{m}$ wide, pale olivaceous to olivaceous- 


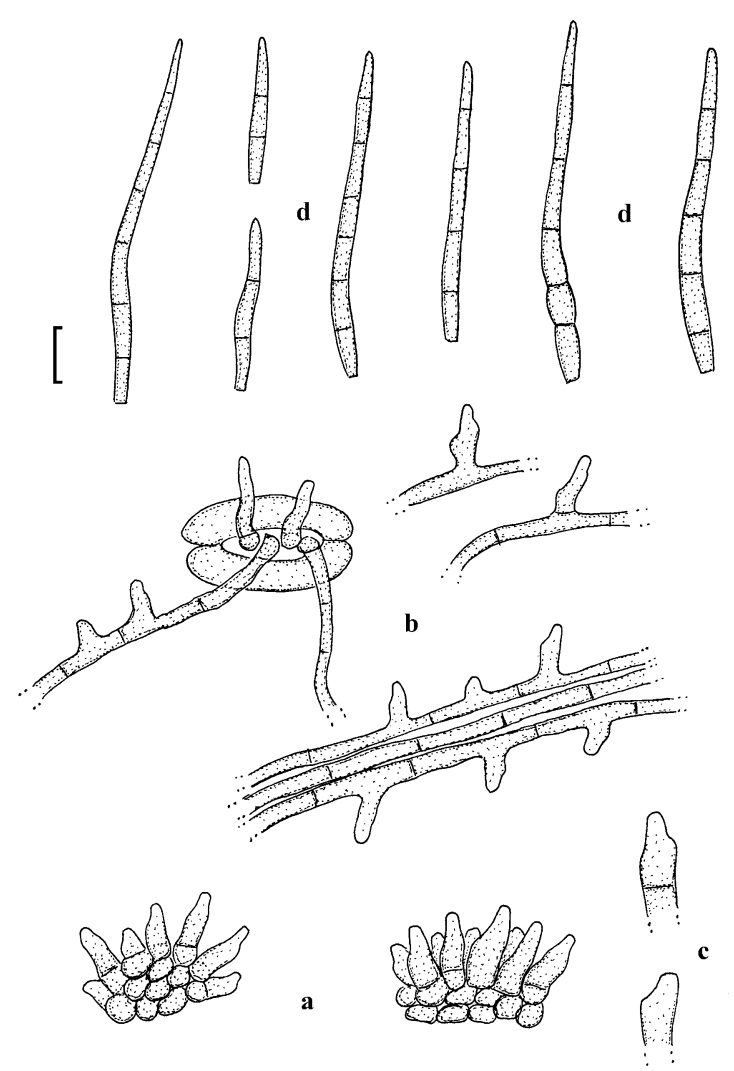

Fig. 8 - Pseudocercospora gonolobicola. Based on type material. a Conidiophore fascicles. b Superficial hyphae with solitary conidiophores. c Conidiophores. $\mathbf{d}$ Conidia. - Bar $=10 \mu \mathrm{m}$.

brown; stromata lacking or small to moderately large, $10-50 \mu \mathrm{m}$ diam., substomatal or intraepidermal, brown, subglobose to irregularly shaped, cells subcircular to angular in outline, 2-6 $\mu \mathrm{m}$ diam. Conidiophores in small, loose to moderately large, dense fascicles, arising from internal hyphae or stromata, emerging through stomata or erumpent through the cuticle, erect, occasionally decumbent, almost straight, subcylindrical to strongly geniculate-sinuous, usually simple or branched, $5-40(-60) \times 2-5$ $\mu \mathrm{m}, 0-3$-septate, pale olivaceous to medium olivaceous-brown, thin-walled, smooth; conidiogenous cells integrated, usually terminal, 4$30 \mu \mathrm{m}$ long, conidiogenous loci (scars) inconspicuous or visible as truncate tips, but neither thickened nor darkened. Conidia solitary, obclavate-cylindrical, $(10-) 15-65 \times 2.5-5 \mu \mathrm{m}$, 1-7(-8)-septate, pale olivaceous to olivaceous-brown, thin-walled, smooth, apex obtuse or only slightly pointed, base obconically truncate, hila $1-2 \mu \mathrm{m}$ wide, unthickened, not darkened.

Material examined - BRAZIL, State of Ceará, Ubajara City, on leaves of Hadroanthus serratifolius (Vahl) S.O. Grose [ $[\equiv$ Tabebuia serratifolia (Vahl) G. Nicholson] (Bignoniaceae), 10 Oct. 2002, F. Freire [U. Braun, Fungi sel. exs. 18] (HAL). INDIA, UP, North Gorakhpur forest Division, on leaves of Tabebuia rosea (Bertol.) DC. (Bignoniaceae), Nov. 1980, R.P. Verma (IMI 257246), isotype of Cercoseptoria tabebuiicola. VENEZELA, without locality, on leaves of Spathodea campanulata P. Beauv. (Bignoniaceae), 14 Mar. 1969, R. Urtiaga 229 (IMI $139309=$ K(M) 179309); Aragua, La Victoria, on leaves of Tabebuia rosea (Bertol.) DC. (Bignoniaceae), 4 Feb. 1928, H. Sydow (BPI 437408, lectotype of Cercospora jahnii, designated here).

Notes - Pseudocercospora jahnii occurs on several species of Tabebuia and related genera and is rather widespread in Central and South America, and also known from Asia (India). P. tabebuiae-roseoalbae (Inácio \& Dianese 1998: 703) and Cercoseptoria tabebuiicola (Kamal et al. 1986: 456) are morphologically not clearly distinguishhable from P. jahnii. Collections on Hadroanthus serratifolius and Spathodea campanulata are also morphologically indistinguishable from $P$. 


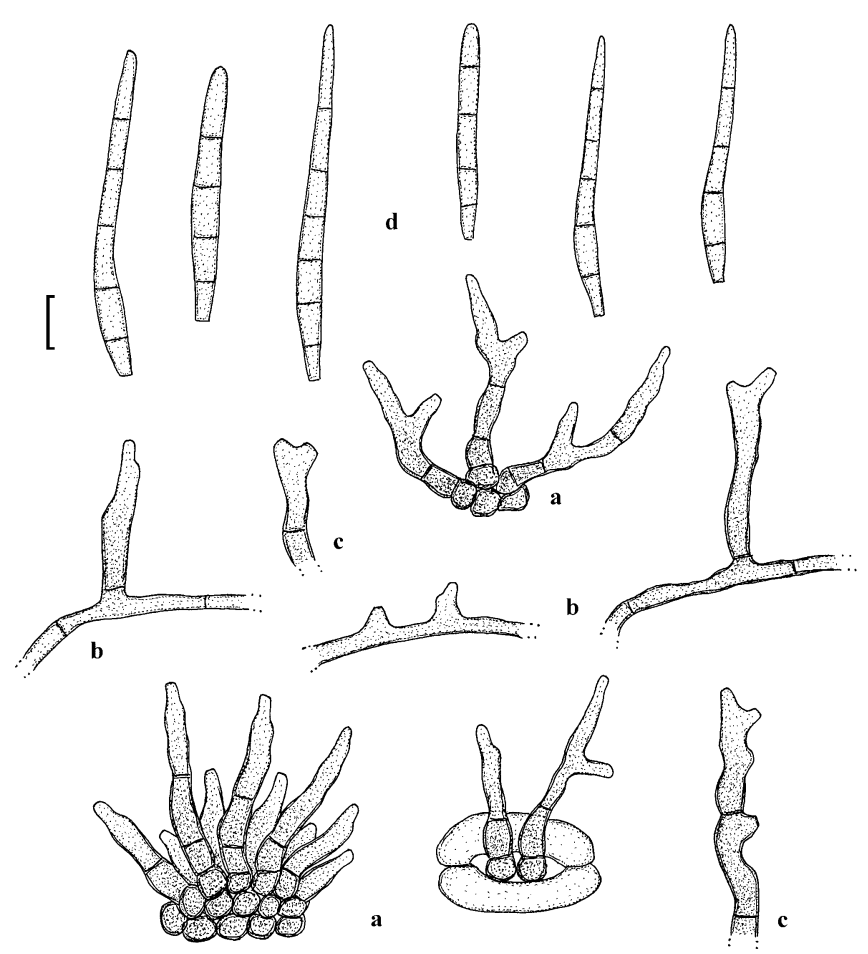

Fig. 9 - Pseudocercospora jahnii var. jahnii on Spathodea campanulata. Based on K(M) 179309. a Conidiophore fascicles. b Superficial hyphae with solitary conidiophores. c Conidiophores. d Conidia. - Bar $=10 \mu \mathrm{m}$.

jahnii. Due to its wide host range and distribution, it is possible that this species represents a complex of closely allied, morphologically barely distinguishable cryptic species. However, this problem can only be solved on the base of cultures and molecular sequence analyses as well as inoculation experiment.

\section{Pseudocercospora jahnii var. amaculata U.} Braun \& Urtiaga, var. nov. Fig. 10 MycoBank, MB 800019.

Etymology - derived from the lack of leaf spots.

Differt a var. jahnii maculis foliorum nullis.

Distinct from var. jahnii by lacking leaf spots.

Material examined - VENEZUELA, without locality, on leaves of Tabebuia shaferi Britton (Bignoniaceae), 14 Mar. 1969, R. Urtiaga 230 (IMI $139210=\mathrm{K}(\mathrm{M})$ 173057, holotype).

Notes - Conidiophores and conidia in the collections on Tabebuia shaferi agree well with Pseudocercospora jahnii, but typical collections of this species form distinct leaf spots. We prefer to introduce a variety for collections without distinct lesions.
Pseudocercospora marcelliana (Chupp) U. Braun \& Crous Fig. 11 三 Cercospora marcelliana Chupp.

Material examined - VENEZUELA, Lara, Sanare, Sabana Redonda Arriba, on leaves of Solanum torvum L. s. lat. [probably var. hartwegianum Sendtner, = var. ochraceo-ferrugineum Dunal, S. rudepannum Dunal] (Solanaceae), Sep. 2010, R. Urtiaga 413 (HAL 2486 F).

Notes - This species, described from Venezuela on Solanum nudum Dunal $[=S$. micranthum Willd. ex Roem. \& Schult. (Chupp 1954)], is Cercoseptoria-like, i.e. with sporodochial conidiomata, numerous densely arranged very short conidiophores, and hyaline or very pale, narrowly cylindrical-filiform to acicular, pluriseptate conidia. In the present collection, the conidiophores are 5-25 $\times 1.5$ $3.5 \mu \mathrm{m}$, and the conidia are $30-110 \times 2-3.5$ $\mu \mathrm{m}, 3-11$-septate. S. torvum is a new host for this species.

Pseudocercospora mikaniigena J.M. Yen \& Lim Fig. 12 $\equiv$ Asperisporium mikaniigena (J.M. Yen \& Lim) R.W. Barreto

Leaf spots amphigenous, subcircular to 


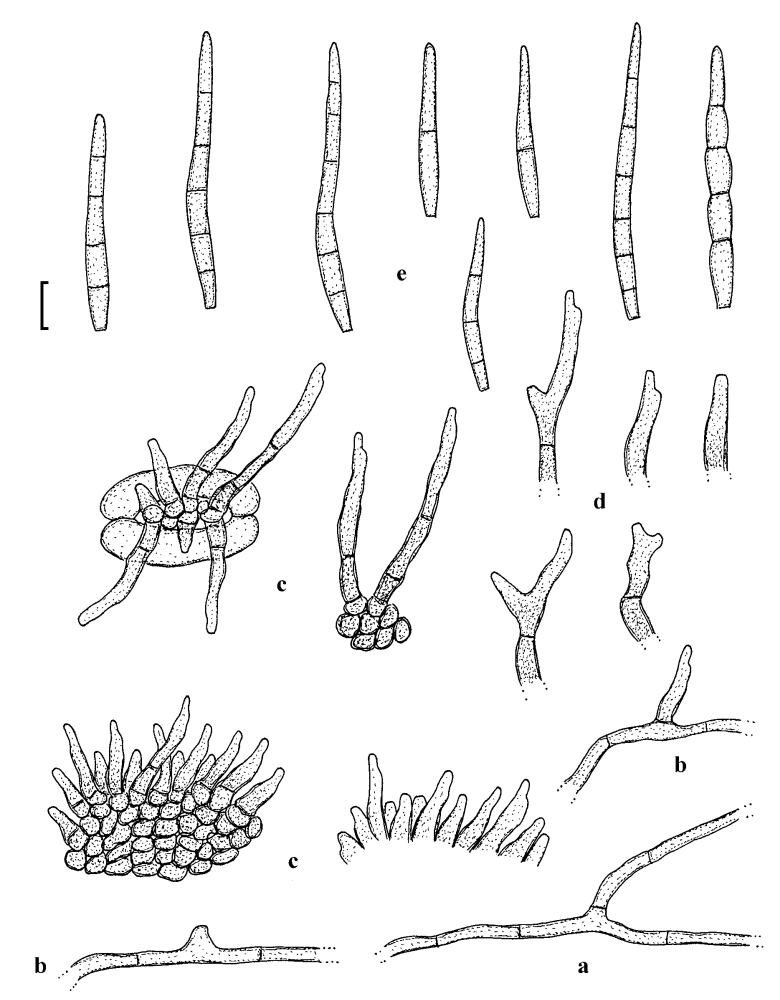

Fig. 10 - Pseudocercospora jahnii var. amaculata. Based on type material. a Superficial hyphae. b Superficial hyphae with solitary conidiophores. c Conidiophore fascicles d Conidiophores. e Conidia. - Bar $=10 \mu \mathrm{m}$.

angular-irregular, brownish to greyish brown or dingy grey, 1-6 mm diam., margin indefinite or with narrow darker marginal line. Caespituli hypophyllous, punctiform, medium to dark brown or blackish brown. Mycelium internal. Stromata lacking or small, substomatal, brown, 10-25 $\mu \mathrm{m}$ diam. Conidiophores in small to moderately large fascicles, divergent to dense, very dense fascicles sometimes subcoremioid, arising from substomatal hyphae or stromata, emerging through stomata, erect, straight, subcylindrical-filiform to moderately geniculate-sinuous, unbranched, 30-110 × 2.5-5 $\mu \mathrm{m}$, continuous to pluriseptate, pale to medium brown or olivaceous-brown, paler towards the tip, thin-walled, smooth; conidiogenous cells integrated, terminal, $10-50 \mu \mathrm{m}$ long, conidiogenous loci inconspicuous to subdenticulate, but always unthickened and not darkened. Conidia solitary, obclavate-subcylindrical, 30$75 \times 3-5 \mu \mathrm{m}, 3-7$-septate, pale olivaceous to olivaceous-brown, thin-walled, smooth, apex obtuse to subacute, base short to longer obconically truncate, $1.5-2 \mu \mathrm{m}$ wide, hila neither thickened nor darkened.
Material examined - VENEZUELA, Lara, Sanare, Sabana Redonda Arriba, on leaves of Mikania cordifolia (L. f.) Willd. (Asteraceae), Sep. 2010, R. Urtiaga 409 (HAL 2492 F).

Notes - Pseudocercospora mikaniigena, described from Malaysia on Mikania cordata (Burm. f.) B.L. Rob., and later recorded from Brazil (Yen \& Lim 1983, Barreto \& Evans 1995), is close to P. plunkettii (Chupp) R.F. Castañeda \& U. Braun (lectotype material examined - on Mikania cordifolia, Mexico, CUP 40596), but the conidiophores of the latter species are much shorter, 10-40 $\mu \mathrm{m}$ long, never coremioid, and the conidia are somewhat narrower. The collection from Venezuela is morphologically close to the original description, except for lacking superficial hyphae with solitary conidiophores. This species is new to Venezuela.

Pseudocercospora mirandensis (Chupp) R.F. Castañeda \& U. Braun

$\equiv$ Cercospora mirandensis Chupp.

Material examined - VENEZUELA, La- 


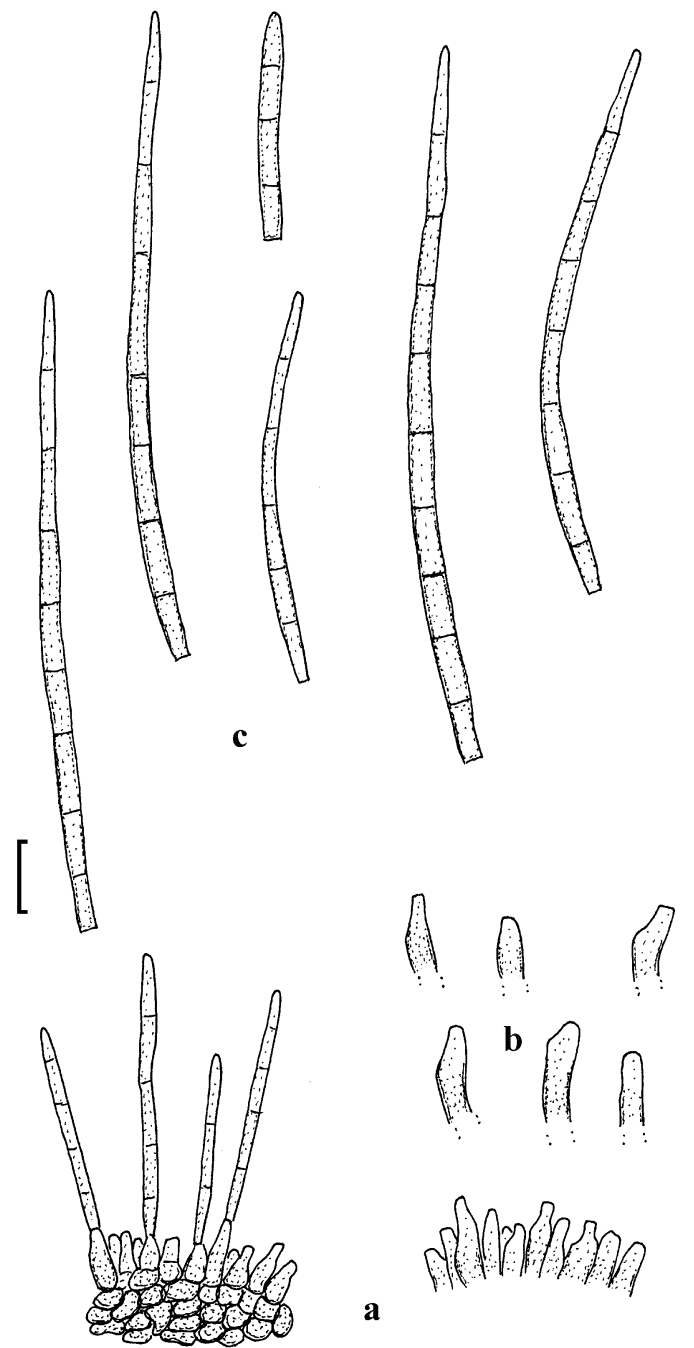

Fig. 11 - Pseudocercospora marcelliana. Based on HAL 2486 F. a Conidiophore fas-cicle. b Conidiophores. c Conidia. - Bar $=10 \mu \mathrm{m}$. Fig. 11 - Pseudocercospora marcelliana. Based on HAL 2486 F. a Conidiophore fas-cicle. b Conidiophores. c Conidia. - Bar $=10 \mu \mathrm{m}$.

ra, Sanare, Sabana Redonda Arriba, on leaves of Miconia sp. (Melastomataceae), Sep. 2010, R. Urtiaga 396 (HAL 2484 F).

Notes - This species was described from Venezuela on Miconia ibaguensis (Bonpl.) Triana. Type material has been examined (Edo Miranda, Santa Lucia, 13 Apr. 1939, Whetzel \& Muller, CUP 3093). Braun \& Urtiaga (2008) recorded this species from Venezuela on Clidemia hirta (L.) D. Don. The present collection on Miconia sp. differs from other samples in almost lacking a lesion.

Pseudocercospora ocimicola (Petr. \& Cif.) Deighton

$$
\equiv \text { Cercospora ocimicola Petr. \& Cif. }
$$

= C. hyptidicola Chupp \& A.S. Mull., nom. inval.

Material examined - VENEZUELA, Lara, Barquisimeto, market, on leaves of Ocimum sanctum L. (Lamiaceae), Jul. 2011, R. Urtiaga 447 (HAL 2475 F).

Notes - This species is known from Venezuela on Hyptis spp. (Braun \& Urtiaga 2008). Ocimum sanctum is a new host for this country.

Pseudocercospora palicoureina (Petr. \& Cif.) U. Braun

$\equiv$ Cercospora palicoureina Petr. \& Cif.

Material examined - VENEZUELA, La-

ra, Sanare, Sabana Redonda Arriba, on leaves 

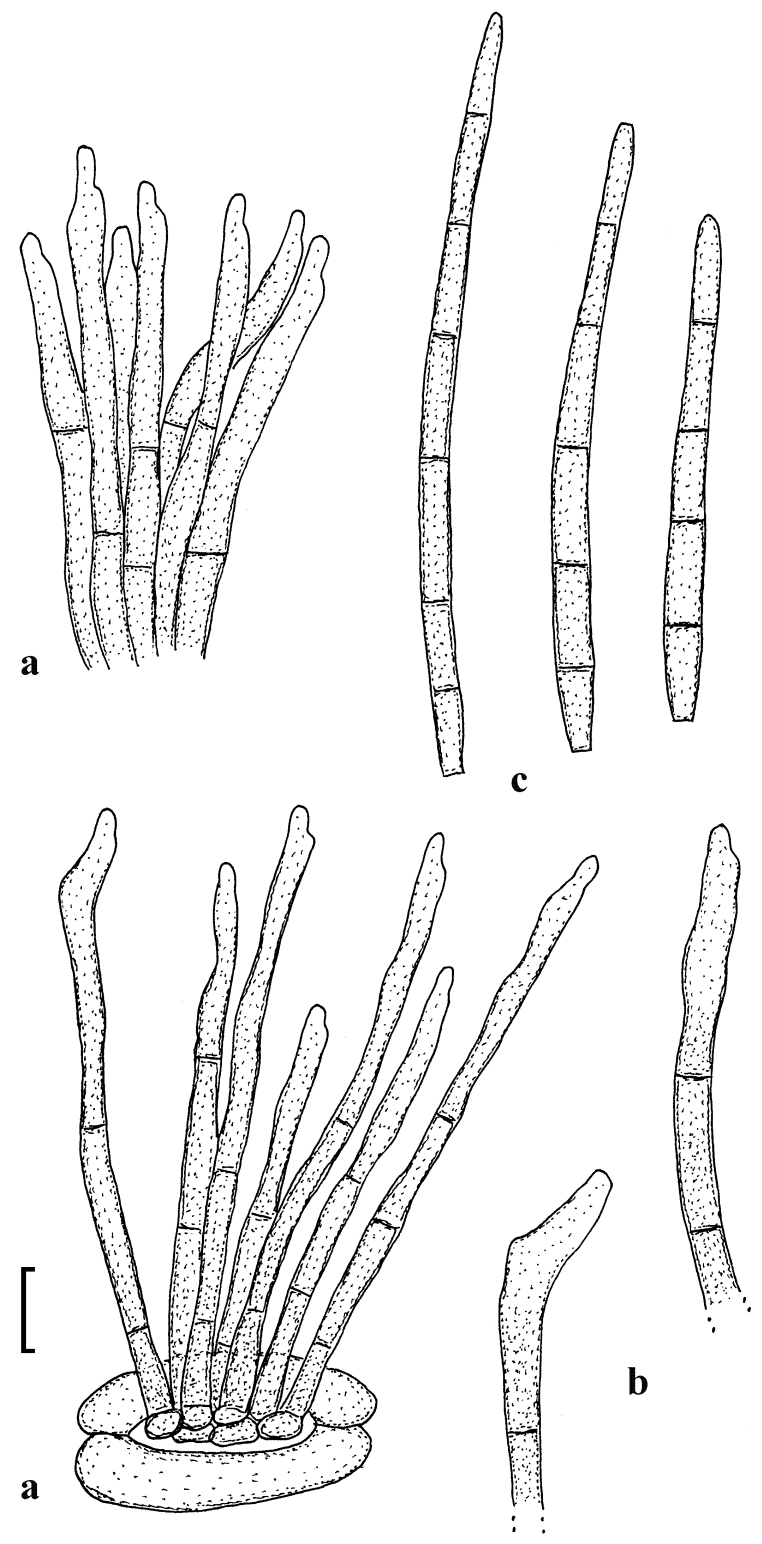

Fig. 12 - Pseudocercospora mikaniigena. Based on HAL 2484 F. a Conidiophore fas-cicles. b Conidiophores. c Conidia. - Bar $=10 \mu \mathrm{m}$.

of Palicourea perquandrangularis Wernham (Rubiaceae), Sep. 2010, R. Urtiaga 416 (HAL 2488 F).

Notes - New host species and new to Venezuela. This collection agrees well with $P$. palicoureina (conidiophores in fascicles, arising from stromata, 10-40 $\mu \mathrm{m}$ diam., $10-60 \times$ 2.5-5 $\mu \mathrm{m}$, conidia obclavate-subcylindrical, 30-65 × 3-4.5 $\mu \mathrm{m}, 3-6$-septate). P. palicoureae O.L. Pereira \& R.W. Barreto (Pereira \& Barreto 2006), described from Brazil on Palicourea marcgravii A. St.-Hill, is characterized by its distinct lesions, lacking stromata, conidiophores solitary or formed in small fascicles emerging through stomata and much longer conidia, up to $115 \mu \mathrm{m}$.

Pseudocercospora pancratii (Ellis \& Everh.) U. Braun \& R.F. Castañeda

$\equiv$ Cercospora pancratii Ellis \& Everh.

= Cercospora hymenocallidis Pat.

Material examined - VENEZUELA, Lara, Barquisimeto, on leaves of Hymenocallis tubiflora Salisb. (Amaryllidaceae), Nov. 2010, R. Urtiaga 428 (HAL 2474 F); 1.c., on leaves of Hymenocallis sp., Sep. 2010, R. Urtiaga 419 (HAL 2473 F).

Notes - New to Venezuela and new host species (Crous \& Braun 2003). P. pancratii is widespread on various hosts of the Amarylli- 
daceae (Crous \& Braun 2003).

Pseudocercospora pehriicola U. Braun \& Urtiaga, sp. nov. Fig. 13

MycoBank, MB 800013.

Etymology - epithet derived from the host genus, Pehria.

Pseudocercosporae lagerstroemiigenae valde similis, sed hospite distincto, maculis differentibus, hyphis superficialibus sparse evolutis, laxis. Differt a P. pehriae hyphis superficialibus cum conidiophoris solitariis et stromatibus formantibus, conidiophoris brevioribus, $10-50 \mu \mathrm{m}$, et conidiis angustioribus, 2$3.5 \mu \mathrm{m}$.

Leaf spots amphigenous, circular to somewhat irregular, $2-10 \mathrm{~mm}$ diam., occasionally zonate, brownish, greyish brown to grey or finally greyish white, with a very narrow dark marginal line, occasionally purple and slightly raised. Caespituli amphigenous, delicately punctiform on the upper side, scattered to aggregated, less conspicuous on the lower surface, dark brown to blackish. Mycelium internal and partly external; superficial hyphae emerging through stomata, sparingly developed, more abundant on the lower surface, sparingly branched, septate, subhyaline to pale olivaceous or olivaceousbrown, smooth, 1-4 $\mu$ m wide. Stromata lacking to well-developed, 10-60 $\mu \mathrm{m}$ diam., on the upper side intraepidermal and larger, substomatal and smaller below, medium to dark brown or olivaceous-brown, cells 3-6 $\mu \mathrm{m}$ diam. Conidiophores in fascicles, epiphyllous fascicles rather large and dense, hypophyllous ones smaller and looser, individual conidiophores almost straight to usually distinctly and strongly geniculate-sinuous, unbranched, $10-50 \times 1.5-4 \mu \mathrm{m}$, aseptate to sparingly septate, pale to medium olivaceous or olivaceous-brown, thin-walled, smooth; conidiogenous cells integrated, terminal or conidiophores reduced to conidiogenous cells, 10$25 \mu \mathrm{m}$ long, conidiogenous loci inconspicuous. Conidia formed singly, narrowly obclavatefiliform, occasionally subacicular, 35-80 $\times 2$ $3.5 \mu \mathrm{m}$, indistinctly 3-8-septate, hyaline, subhyaline to very pale olivaceous, thin-walled, smooth, apex acute to subobtuse, base usually obconically truncate, occasionally truncate, 11.5 $\mu \mathrm{m}$ wide, hila neither thickened nor darkened.

Material examined - VENEZUELA, Carabobo State, Miranda, on leaves of Pehria compacta (Rusby) Sprague (Lythraceae), Apr. 2011, R. Urtiaga 434 (HAL 2483 F, holotype).

Notes - Braun \& Urtiaga (2008) described Pseudocercospora pehriae on Pehria compacta from Venezuela. This species is, however, quite distinct from $P$. pehriicola by lacking superficial mycelium and stromata, very long conidiophores, up to $150 \mu \mathrm{m}$, and broadly obclavate-cylindrical conidia, 20-70 $\times$ 4-7 $\mu \mathrm{m}$. Several additional Pseudocercospora species on hosts belonging to diverse genera of the Lythraceae are known. The Asian $P$. lagerstroemiigena Goh \& W.H. Hsieh on Lagerstroemia speciosa (Hsieh \& Goh 1990) is very similar, but differs in forming different lesions and well-developed superficial hyphae, partly dense and aggregated in ropes. $P$. lagerstroemiae-lanceolatae U. Braun \& Crous (Crous \& Braun 2003) and P. lythri H.D. Shin \& U. Braun (Shin \& Kim 2001) are two species that form superficial mycelium, but the former differs in having very long, pluriseptate conidiophores, up to $100 \mu \mathrm{m}$, and the latter has wider conidia, 3-5 $\mu \mathrm{m}$. In other species with similarly narrow conidia, the conidiophores are consistently fasciculate, i.e. solitary conidiophores and superficial hyphae are lacking, viz. P. cupheae (Syd.) U. Braun, P. lythracearum (Heald \& F.A. Wolf) X.J. Liu \& Y.L. Guo (incl. P. lagerstroemiae-subcostatae (Sawada) Goh \& W.H. Hsieh), P. neseae (Ellis \& Everh.) U. Braun, P. woodfordiigena U. Braun \& Crous (Chupp 1954, Hsieh \& Goh 1990, Guo \& Hsieh 1995). P. sydowiana (Chupp) U. Braun \& Crous is characterized by its very long conidiophores, up to $260 \mu \mathrm{m}$, and broad conidia $20-70 \times 4-7 \mu \mathrm{m}$, and $P$. lagerstroemiae-parviflorae H.S.G. Rao, S. Narayan \& Bhartiya has very long, pluriseptate conidiophores, up to $204 \mu \mathrm{m}$, and somewhat wider conidia, 3-5 $\mu \mathrm{m}$ (Chupp 1954, Goh \& Hsieh 1990, Rao et al. 1996).

Pseudocercospora punicae (Henn.) Deighton

$\equiv$ Cercospora punicae Henn.

Material examined - VENEZUELA, Lara, Barquisimeto, on leaves of Punica granatum L. (Punicaceae), Sep. 2010, R. Urtiaga 404 (HAL 2485 F). 


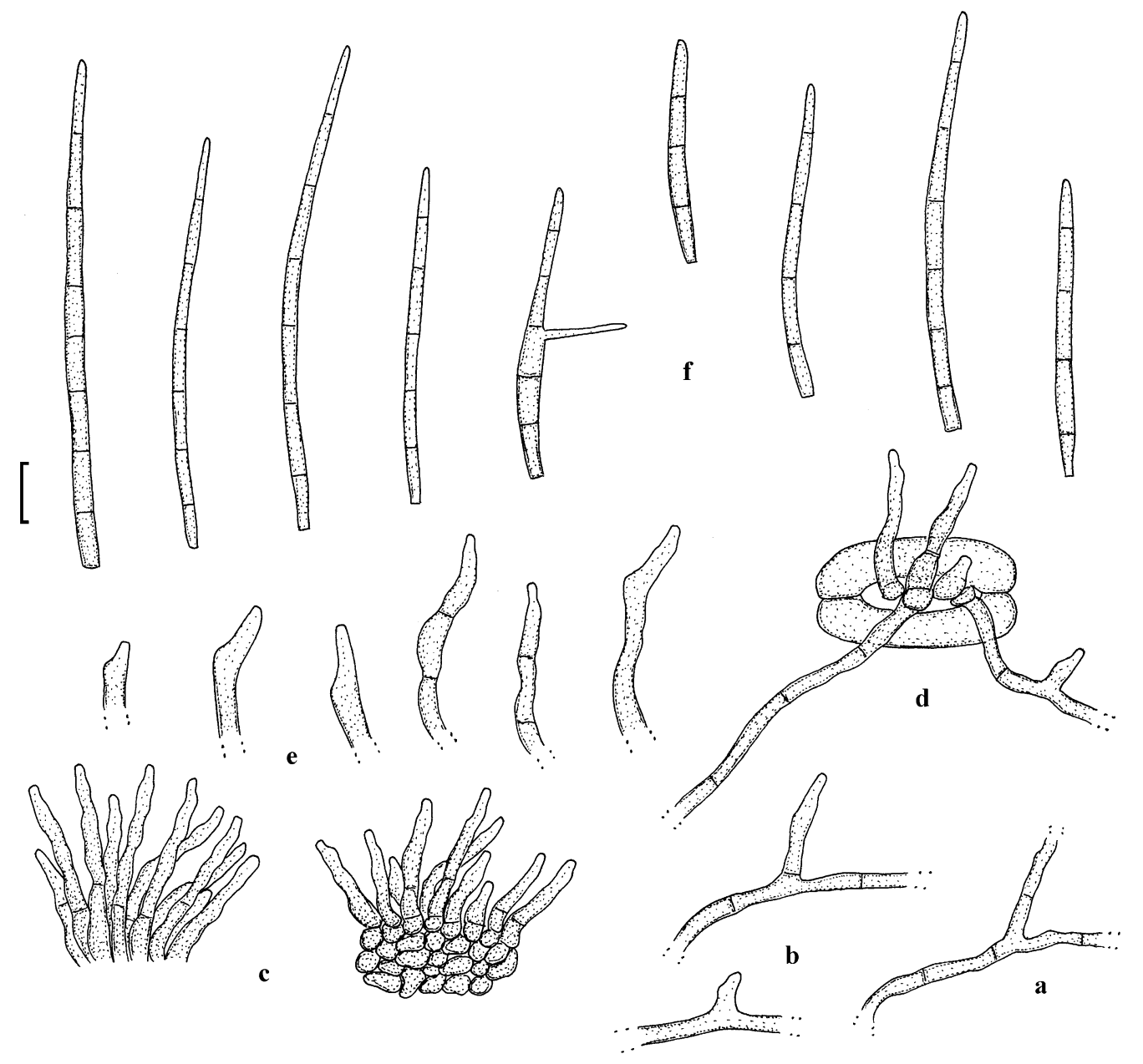

Fig. 13 - Pseudocercospora pehriicola. Based on type material. a Superficial hyphae. b Superficial hyphae with solitary conidiophores. c Conidiophore fascicle. d Conidiophores and hyphae emerging through a stoma. e Conidiophores, f Conidia $-\mathrm{Bar}=10 \mu \mathrm{m}$.

Notes - Known from Venezuela (Crous $\&$ Braun 2003).

\section{Pseudocercospora rauvolfiae-tetraphyllae U.} Braun \& Urtiaga, sp. nov. Fig. 14 MycoBank, MB 800014.

Etymology - epithet derived from the host species, Rauvolfia tetraphylla.

Differt ab omnibus speciebus Pseudocercosporae ad Bignoniaceas ( $P$. liebenbergii, $P$. rauvolfiae, $P$. rauwolfiae-serpentinae et $P$. serpentinae) caespitulis epiphyllis et hypophyllis distincte dimorphis (caespitulis epiphyllis punctiformibus, stromatibus intraepidermalibus bene evolutis, 15-60 $\mu \mathrm{m}$ diam., conidiophoris numerosis, dense fasciculatis; caespitulis hypophyllis indistinctis, stromatibus nullis vel parvis, substomatalibus, conidiophoris parvis, laxe fasciculatis, interdum valde ramosis, hyphis superficialibus cum conidiophoris solitariis formantibus).

Leaf spots amphigenous, angular-irregular, 1-10 mm diam., on the upper leaf surface at first brown to dark brown, later with pale centre, greyish brown to dingy grey, with a narrow to moderately broad darker margin, on the lower side paler brown and margin indefinite. Caespituli amphigenous, on the upper side punctiform, dark brown to blackish, scattered to aggregated, below rather inconspicuous. Mycelium internal and external on the lower surface; superficial hyphae emerging through stomata, straight to sinuous, branched, 1-4 $\mu \mathrm{m}$ wide, septate, subhyaline to pale olivaceous-brown, smooth; stromata on the upper side well-developed, intraepidermal, brown, 15-60 $\mu \mathrm{m}$ diam., erumpent, subcircular to somewhat irregular in outline, lacking or 

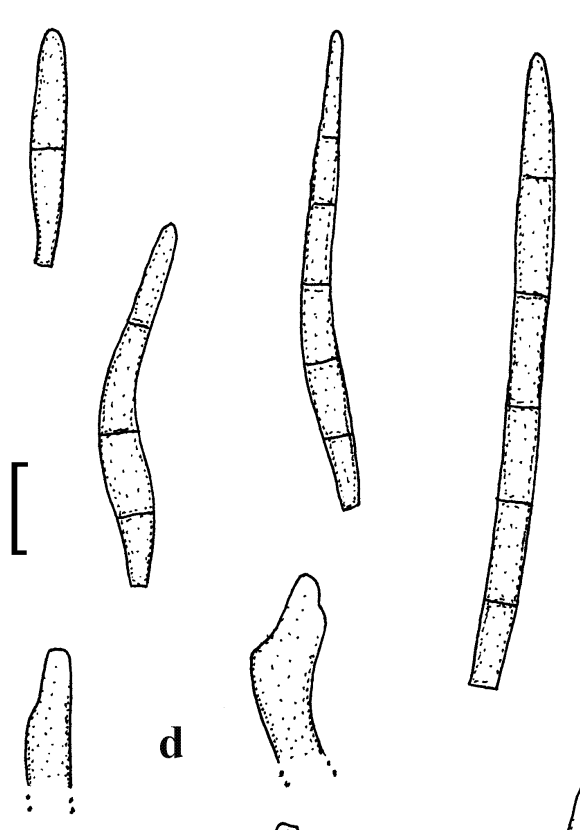

$\mathbf{e}$
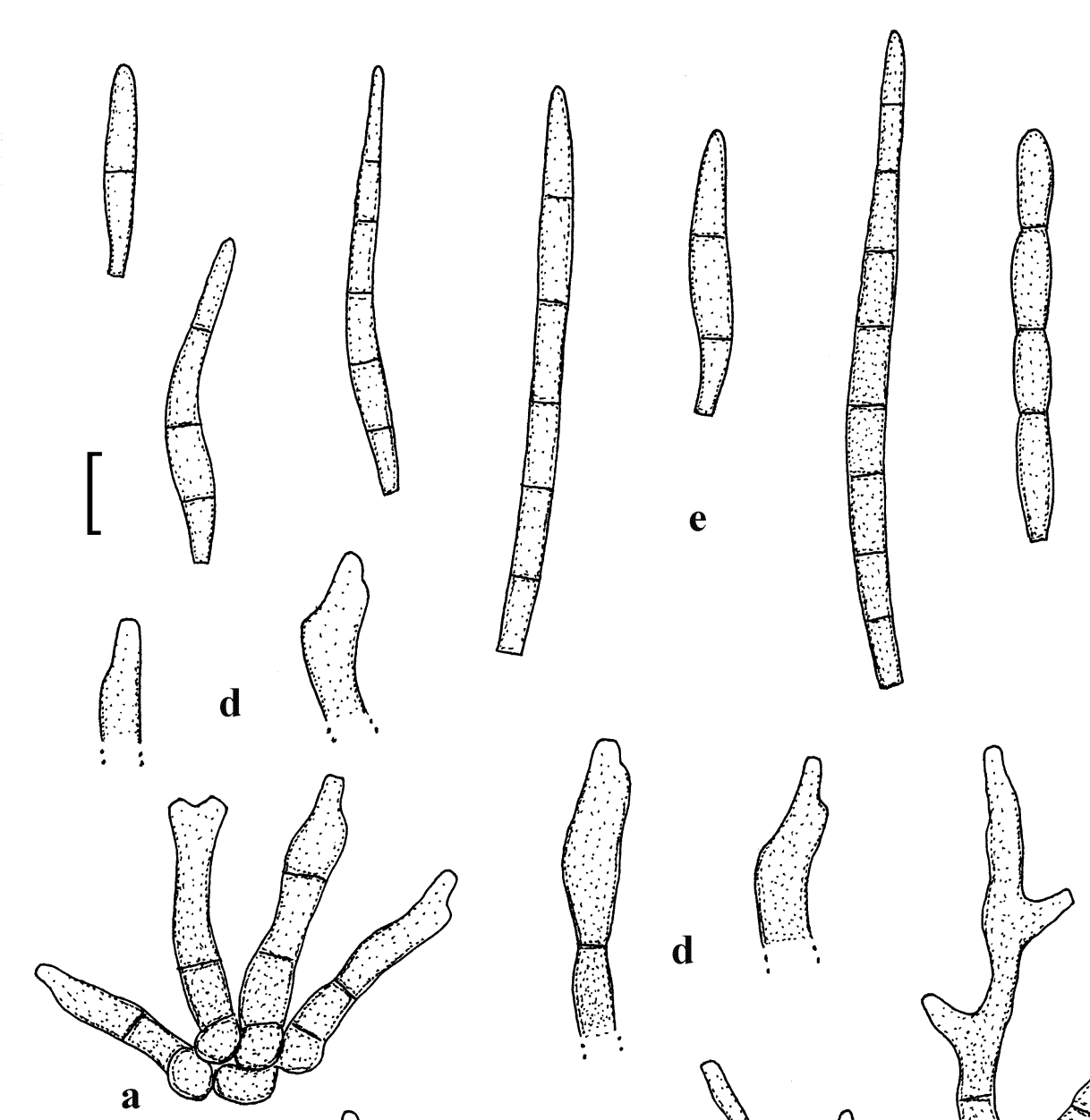

d
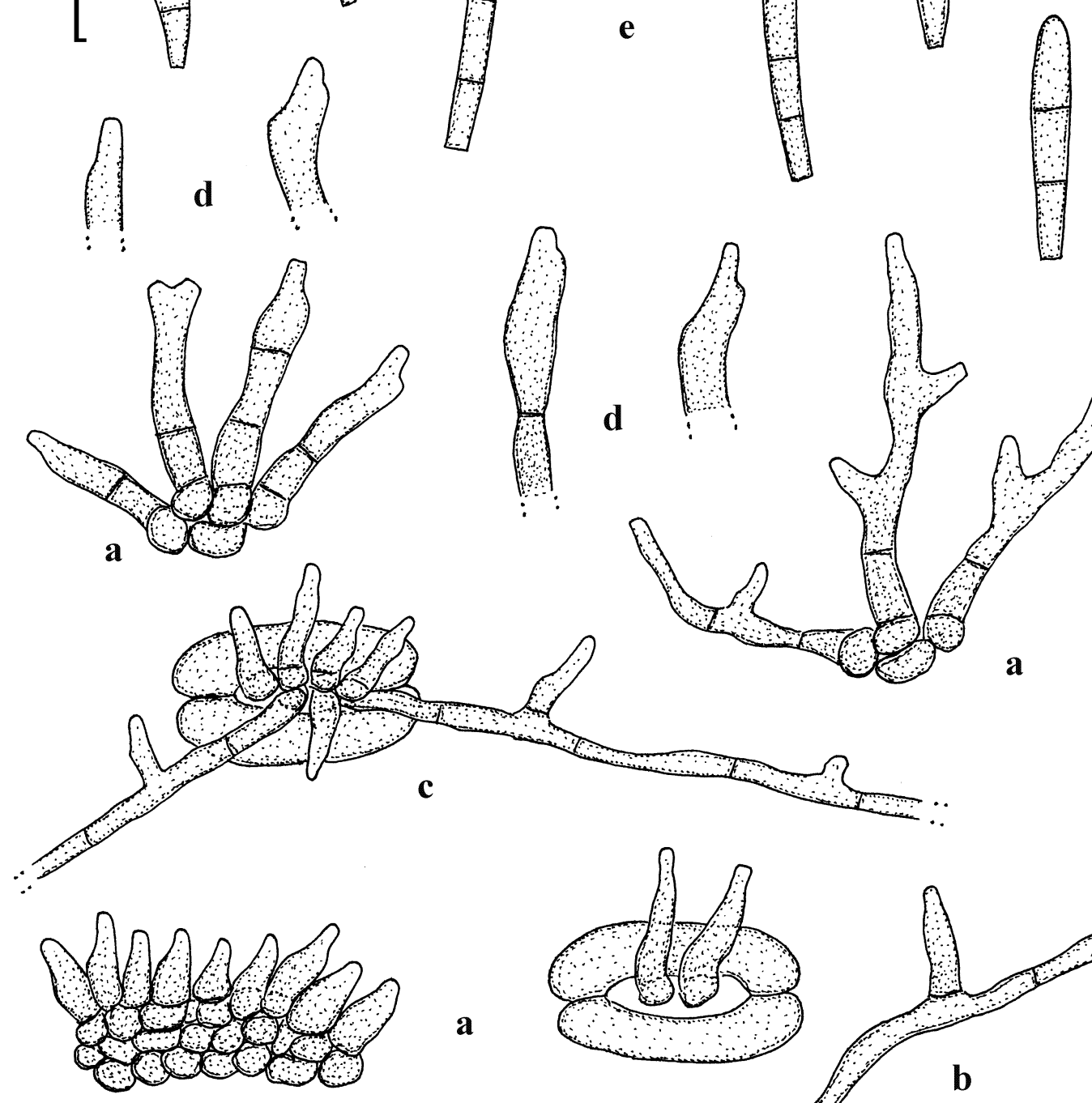

a

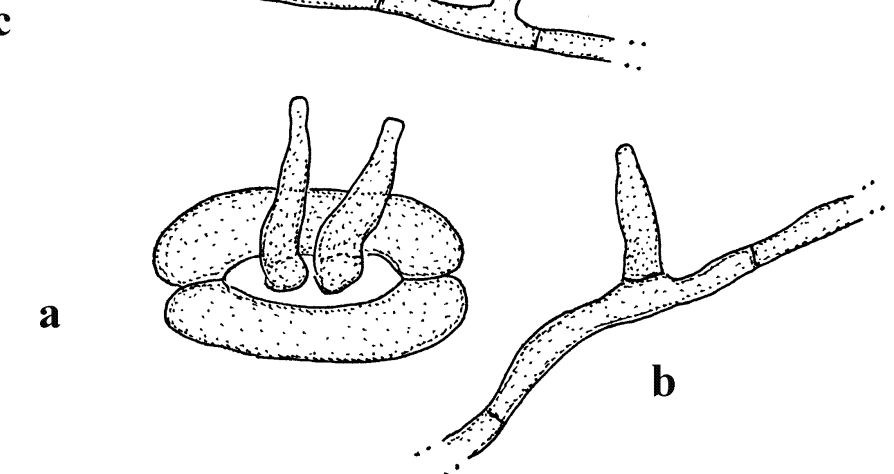

Fig. 14 - Pseudocercospora rauvolfiae-tetraphyllae. Based on type material. a Conidiophore fascicles. b Hypha with solitary conidiophore. c Conidiophores and hyphae emerging through a stoma. d Conidiophores. e Conidia - Bar $=10 \mu \mathrm{m}$.

only small below, substomatal, cells $2-5 \mu \mathrm{m}$ diam. Conidiophores on the upper leaf surface in small to moderately large, often dense fascicles, arising from stromata, erumpent, on the lower side in smaller and usually looser fascicles, arising from internal hyphae or small stromata, emerging through stomata, or soli- tary, arising from superficial hyphae, lateral, straight, subcylindrical, subclavate or slightly attenuated towards the tip, unbranched or hypophyllously sometimes slightly to strongly branched, (5-)10-40 × 2-5 $\mu \mathrm{m}, 0-2$-septate, thin-walled, smooth, pale to medium olivaceous or olivaceous-brown; conidiogenous 
cells integrated, terminal or conidiophores reduced to conidiogenous cells, 5-30 $\mu \mathrm{m}$ long, conidiogenous loci inconspicuous. Conidia formed singly, obclavate-cylindrical, short conidia sometimes ellipsoid-subcylindrical or fusoid, $15-80 \times 2-4.5 \mu \mathrm{m}, 1-7$-septate, subhyaline to pale olivaceous or olivaceousbrown, smooth, apex obtuse to subacute, base short obconically truncate, $1.5-2 \mu \mathrm{m}$ wide, hila neither thickened nor darkened.

Material examined - CUBA, Bayamo, on leaves of Rauvolfia tetraphylla L. (Apocynaceae), 27 Feb. 1967, R. Urtiaga (IMI 126169 $=\mathrm{K}(\mathrm{M})$ 173068, holotype); CUBA, Bayamo, on leaves of $R$. tetraphylla, 12 Nov. 1966, R. Urtiaga (IMI $123577=\mathrm{K}(\mathrm{M})$ 173066); CUBA, Bayamo, on leaves of $R$. tetraphylla, $12 \mathrm{Feb}$. 1967, R. Urtiaga (IMI $126081=\mathrm{K}(\mathrm{M})$ 173067). VENEZUELA, without locality, on leaves of $R$. tetraphylla, 11 Jul. 1969, R. Urtiaga 389 (IMI $141512=\mathrm{K}(\mathrm{M})$ 173072).

Notes - This species, known from Cuba and Venezuela on Rauvolfia tetraphylla, differs from all other species of Pseudocercospora on Rauvolfia spp. in forming characteristically dimorphic fructification, i.e. with obvious differences between epiphyllous and hypophyllous caespituli. On the upper leaf surface, welldeveloped intraepidermal stromata with large, dense fascicles of conidiophores are developed, whereas on the lower side stromata are lacking or small, substomatal, and the conidiophores, sometimes distinctly branched, are formed in small, divergent fascicles and superficial hyphae with solitary conidiophores are also developed. In $P$. rauvolfiae Deighton (Deighton 1983), described from Africa (Guinea and Sierra Leone) on Rauvolfia vomitoria Afzel., superficial hyphae with solitary conidiophores are lacking and the conidiophores are longer, up to $85 \mu \mathrm{m}$, mostly 30-50 $\mu \mathrm{m}$. The Indian $P$. serpentinae (Pandotra \& Husain) Deighton (Deighton 1976, 1983) on $R$. serpentina (L.) Benth. ex Kurz is characterized by lacking stromata, effuse hypophyllous colonies, frequently branched conidiophores and abundant superficial hyphae with solitary conidiophores. $P$. rauwolfiaeserpentinae H.S. Rao, Arch. Singh \& Kamal (Rao et al. 1995), also described on $R$. serpentina from India, is close to $P$. rauvolfiae (conidiophores arising from stromata, super- ficial hyphae lacking) and was reduced to synonymy with the latter species in Kamal (2010). However, P. rauwolfiae-serpentinae should rather be separated from the African species due to its much shorter conidiophores and conidia. P. liebenbergii (Syd.) Deighton, confined to $R$. caffra Sond. in South Africa, is quite distinct from $P$. rauvolfiae-tetraphyllae. The conidiophores often proliferate percurrently, the conidia become rough-walled, and superficial hyphae are lacking (Chupp 1954, Deighton 1976, Crous \& Braun 1996). Chupp (1954) recorded this species from Venezuela on Rauvolfia sp. The material concerned has not been seen, but it is possible that this record refers to $P$. rauvolfiae-tetraphyllae.

\section{Pseudocercospora tibouchinae (Viégas) Deighton Fig. 15 \\ $\equiv$ Cercospora tibouchinae Viégas. \\ $\equiv$ Cercoseptoria tibouchinae (Viégas) Deighton}

Material examined - VENEZUELA, Lara, Sanare, Sabana Redonda Arriba, on leaves of Tibouchina longifolia (Vahl) Baill. (Melastomataceae), Sep. 2010, R. Urtiaga 407 (HAL $2490 \mathrm{~F}$ ).

Notes - This species has been described from Brazil on Tibouchina sp. Type material was re-examined and redescribed by Crous et al. (1997). This is the first record of this species from Venezuela, and T. longifolia is a new host species (Crous \& Braun 2003). The material from Venezuela agrees well with type material of this species (conidiophores arising from well-developed stromata, short and aseptate, 5-20 $\times 2-3 \mu \mathrm{m}$, forming sporodochial conidiomata; conidia solitary, narrowly cylindrical-filiform to somewhat acicular, up to $90 \times$ 2-3.5 $\mu \mathrm{m}$, pluriseptate, apex obtuse to subacute, base truncate to short obconically truncate).

Pseudocercospora trichophila var. punctata U. Braun \& Urtiaga, var. nov. Fig. 16 MycoBank, MB 800018.

Etymology: the name of the variety refers to the presence of punctiform epiphyllous caes-pituli.

Differt a var. trichophila caespitulis amphigenis, in epiphyllo punctiformibus, e stromatibus, $10-50 \mu \mathrm{m}$ diam., et conidiophoris fas- 

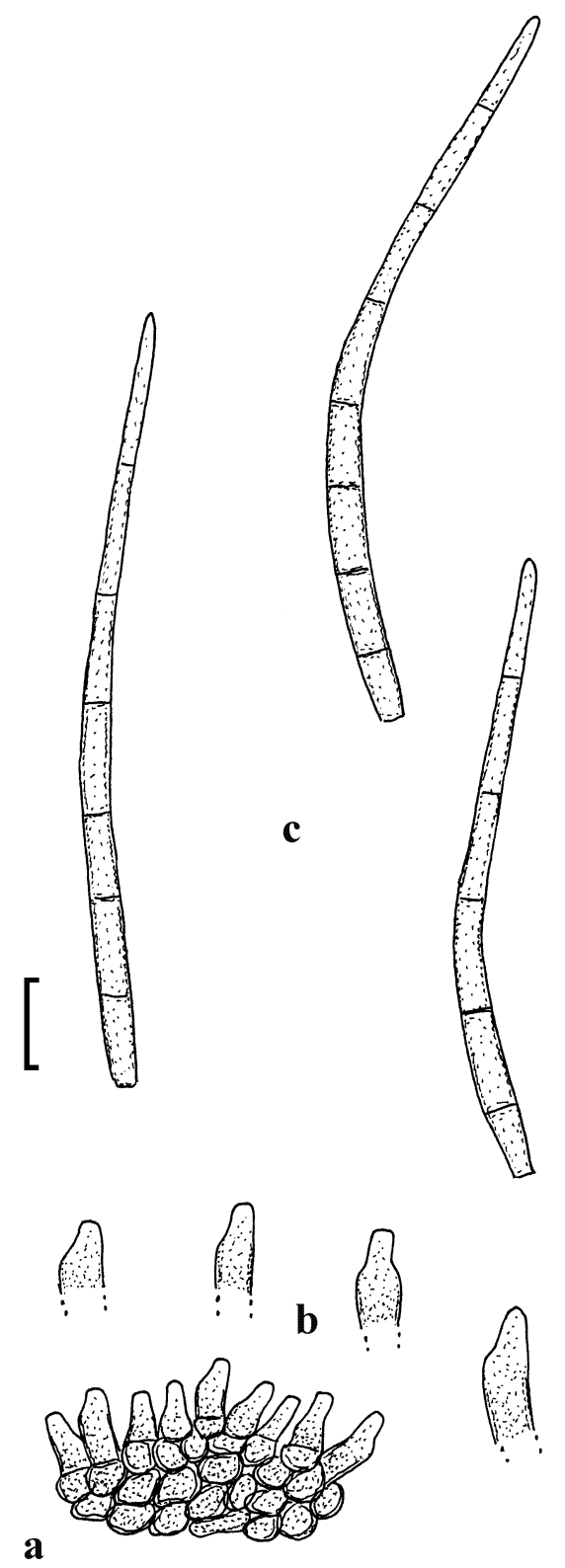

Fig. 15 - Pseudocercospora tibouchinae. Based on HAL 2490 F. a Conidiophore fascicle. b Conidiophores. c Conidia. - Bar $=10 \mu \mathrm{m}$.

ciculatis compositis.

Leaf spots amphigenous, $2-8 \mathrm{~mm}$ diam., subcircular to angular-irregular,brownish, greyish brown, dingy grey, with narrow darker border or halo on the upper leaf surface, hypophyllous leaf spots less conspicuous, with indistinct margin. Caespituli amphigenous, on the upper leaf surface punctiform, dark brown, effuse and less conspicuous below. Mycelium internal and external, superficial hyphae usually lacking on the upper side, abundant below, emerging through stomata, sparingly branched, 1-3.5 $\mu \mathrm{m}$ wide, septate, hyaline, subhyaline to pale olivaceous or olivaceous- brown, thin-walled, smooth; stromata small to well-developed on the upper side, intraepidermal, 10-50 $\mu \mathrm{m}$ diam., medium to dark olivaceous-brown, lacking or very small below. Conidiophores on the upper side in small to moderately large fascicles, loose to dense, arising from stromata, erect, straight, subcylindrical to geniculate-sinuous, unbranched, $10-70 \times 3-5 \mu \mathrm{m}$, pale olivaceous to medium olivaceous-brown, 0-4-septate, thin-walled, smooth, on the lower side solitary, arising from superficial hyphae, lateral, occasionally terminal, short, 3-25 × 2.5-5 $\mu \mathrm{m}$, conical-subcylindrical, $0-1$-septate; conidiogenous cells 
integrated, terminal or conidiophores reduced to conidiogenous cells, 3-20 $\mu \mathrm{m}$ long, conidiogenous loci inconspicuous or subdenticulate, but always unthickened and not darkened. Conidia solitary, subcylindrical or oblavatecylindrical, $(10-) 25-90(-110) \times(2.5-) 3-5 \mu \mathrm{m}$, (1-)3-10(-12)-septate, distance between septa 6-18 $\mu \mathrm{m}$, subhyaline to pale olivaceous, apex obtuse, rounded to somewhat pointed, base obconically truncate, $1-1.5(-2) \mu \mathrm{m}$ wide, hila neither thickened nor darkened.

Material examined - VENEZUELA, Lara, Sanare, Sabana Redonda Arriba, on leaves of Solanum hirtum Vahl (Solanaceae), Jun. 2010, R. Urtiaga 377 (HAL 2498 F, holotype).

Notes - Deighton (1976) examined type material and numerous other collections of Pseudocercospora on Solanum spp. and provided a detailed description and some drawings of the morphologically variable Pseudocercospora trichophila (F. Stevens) Deighton, reduced several Cercospora spp. to synonymy with the latter species and discussed it in detail. In the type material of $P$. trichophila and its synonyms, colonies are chiefly hypophyllous, stromata are lacking and the conidiophores are formed singly, arising from superficial hyphae. In the present collection from Venezuela, the hypophyllous fructification agrees perfectly with typical $P$. trichophila, but additional epiphyllous caespituli are formed which are punctiform, composed of immersed stromata and fasciculate conidiophores. The conidia agree with those in typical collections of $P$. trichophila. We prefer to assign such collections with additional fasciculate conidiophores arising from stromata to a special morphological variety of the latter species. Var. punctata undoubtedly occurs on other Solanum spp. as well. Hsieh \& Goh (1990: 321, Fig. 243) illustrated, for instance, an agreeing collection from Taiwan on Solanum aculeatissimum Jacq. Conidia in var. trichophila are (3-)4-5(-7) $\mu \mathrm{m}$ wide. Collections on Solanum asperum Rich. (Brazil and Trinidad), described as Cercospora solaniasperi (Trinidad, Arima Forest Reserve, 25 Oct. 1947, W.T. Dale, Fungi of Trinidad 1729, IMI 24507, type, examined), are barely distinct from $P$. trichophila, but due to somewhat narrower conidia, Deighton (1976) introduced the combination Pseudocercospora solani- asperi and tentatively maintained it as separate species. However, the latter is barely more than an additional variety of the morphologically variable $P$. trichophila.:

Pseudocercospora trichophila var. solaniasperi (R.E.D. Baker \& W.T. Dale) U. Braun, comb. et stat. nov.

MycoBank, MB 800044.

Basionym: Cercospora solani-asperi $\mathrm{R}$. E.D. Baker \& W.T. Dale, Mycol. Pap. 33: 105, 1951.

$\equiv$ Pseudocercospora solani-asperi (R.E. D. Baker \& W.T. Dale) Deighton, Mycol. Pap. 140: 113, 1976.

\section{Pseudocercosporella capsellae (Ellis \&} Everh.) Deighton

Material examined - VENEZUELA, Lara, Barquisimeto, market, on leaves of Brassica rapa subsp. pekinensis Kitam. (Brassicaceae), Jul. 2011, R. Urtiaga 446 (HAL 2476 F).

Notes - New to Venezuela (Braun 1995, IMI Descriptions of Fungi and Bacteria 161, Sheet 1605, 2004).

Zasmidium asclepiadis U. Braun \& Urtiaga, sp. nov. Fig. 17

MycoBank, MB 800015.

Etymology - epithet derived from the host genus, Asclepias.

Differt ab omnibus speciebus Zasmidii (et Stenellae) ad Asclepiadaceas (Z. ceropegiae, Z. cynanchi, Z. gongronematis, Z. pentatropidis et $Z$. telosmae) conidiophoris valde brevioribus, modo 5-40 $\mu \mathrm{m}$ longis et conidiophoris simplicibus, 0-2-septatis.

On living and faded leaves, lesions subcircular or with diffuse, irregular discolorations, brownish to reddish. Colonies hypophyllous, effuse, thin, grey to dingy greyish brown, in older colonies hyphae, conidiophores and conidia sometimes with a reddish tinge. Mycelium internal and external; superficial hyphae emerging through stomata, sparingly branched, septate, thin-walled, vegetative hyphae 1-3 $\mu \mathrm{m}$ wide, hyaline to very pale olivaceous, rough-walled, fertile hyphae or hyphal cells with conidiophores somewhat wider, darker and mostly more or less smooth; stromata lacking. Conidiophores solitary, arising from superficial hyphae, lateral, rarely 


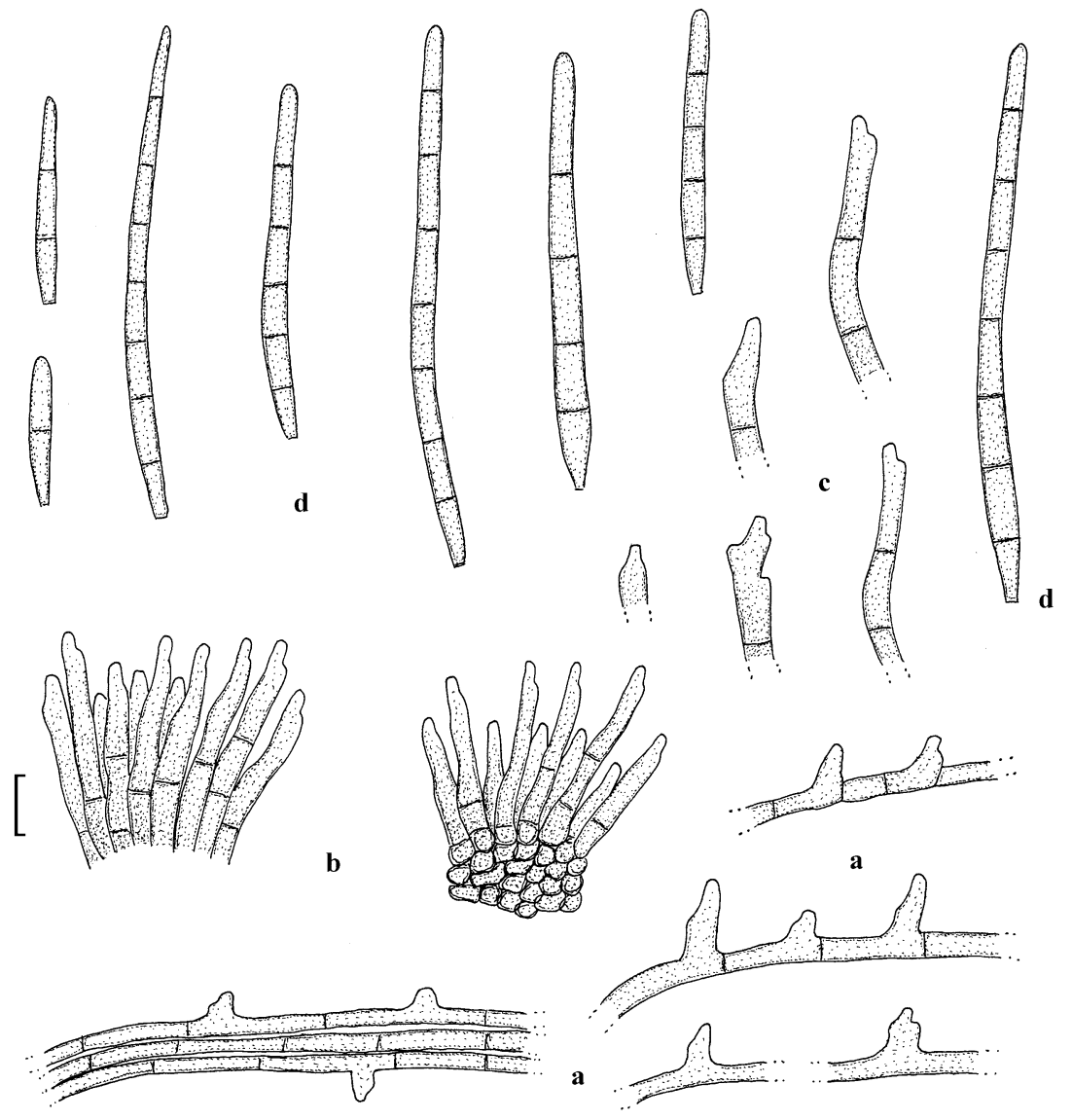

Fig. 16 - Pseudocercospora trichophila var. punctata. Based on type material. a Superficial hyphae with solitary conidiophores. b Conidiophore fascicles. $\mathbf{c}$ Conidiophores. d Conidia. - Bar $=10 \mu \mathrm{m}$.

terminal, with 1-2(-3) conidiophores per cell, occasionally with a few fasciculate conidiophores emerging through stomata, erect, straight, subcylindrical to moderately geniculate-sinuous, simple or sometimes once to olivaceous, olivaceous-brown, brown or reddish brown, thin-walled, smooth, later several times branched, 5-40 × 2.5-6 $\mu \mathrm{m}$, unbranched conidiophores 0-2-septate, longer branched conidiophores often with additional septa, pigmentation variable, subhyaline, pale sometimes somewhat rough-walled; conidiophores integrated, terminal, conidiophores aseptate, i.e. reduced to conidiogenous cells, or conidiogenous cells integrated in superficial hyphae, with lateral peg-like protuberances, 5$20 \mu \mathrm{m}$ long, with a single to several conspicuous conidiogenous loci, circular in outline, thickened and darkened, 1-1.5 $\mu \mathrm{m}$ diam. Conidia formed singly, rarely in short chains, narrowly cylindrical-obclavate, short conidia sometimes narrowly ellipsoid-fusoid, (6-)10$60(-100) \times 2-3.5 \mu \mathrm{m},(0-) 1-6(-8)$-septate, hyaline or subhyaline, thin-walled, smooth, apex subacute to subobtuse, base short obconically truncate, $1-1.5 \mu \mathrm{m}$ wide, hila slightly thickened and darkened.

Material examined - VENEZUELA, without locality, on leaves of Asclepias curassavica L. (Asclediadaceae), 23 Jan. 1970, R. Urtiaga 915 (IMI $146225=\mathrm{K}(\mathrm{M})$ 173065, holotype).

Notes - Several species of Zasmidium have been described on hosts belonging to the Asclediadaceae, but all of them have much longer, pluriseptate conidiophores. Furthermore, Zasmidium gongronematis (J.M. Yen \& Gilles) U. Braun comb. nov. (Bas.: Cercospora gongronematis J.M. Yen \& Gilles, Bull. Trimest. Soc. Mycol. France 137: 69, 1974; MycoBank, MB 800043), a typical Zasmidium with planate conidiogenous loci and conidial hila, differs from $Z$. asclepiadis in having broader $(4-5 \mu \mathrm{m})$, cylindrical conidia (Yen 1975). Z. pentatropidis (K. Srivast., A.K. Srivast. \& Kamal) Kamal (Kamal 2010) and Z. 


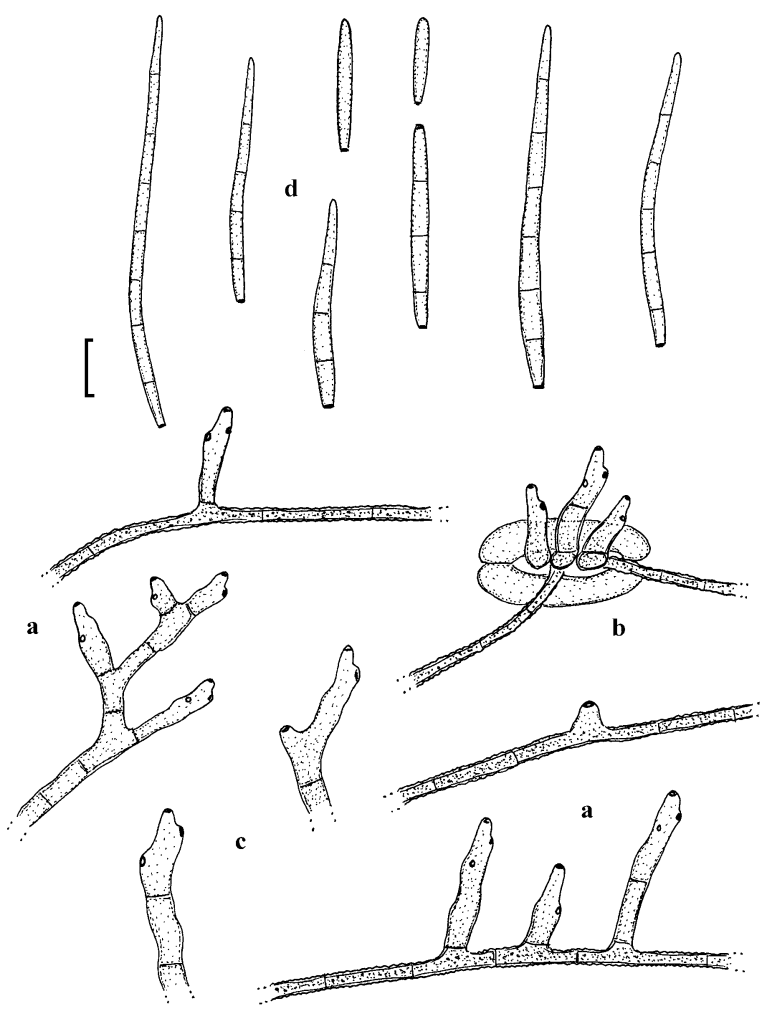

Fig. 17 - Zasmidium asclepiadis. Based on type material. a Superficial hyphae with solitary conidiophores. b Conidiophores and hyphae emerging through a stoma. c Conidiophores. d Conidia. - Bar $=10 \mu \mathrm{m}$.

telosmae (K. Srivast., A.K. Srivast. \& Kamal) Kamal (Kamal 2010) are characterized by having verruculose conidia, which are also wider $(3-6 \mu \mathrm{m})$ in the latter species. In Stenella ceropegiae M.S. Patil \& Sawant (Patil \& Sawanat 1991) on Ceropegia bulbosa Roxb. in India, the conidiophores are formed in fascicles, but superficial hyphae with solitary conidiophores are lacking. The Indian $S$. cynanchi J.M. Yen, A.K. Kar \& B.K. Das (Yen et al. 1982b) is characterized by its small, 7-23 $\times 2.5-3.5 \mu \mathrm{m}, 0-1$-septate conidia. The latter two species have not yet been re-examined. Type material was not available. Therefore, the generic affinity of these species is still unclear.

\section{Acknowledgements}

We are much obliged to the mycology curator of the Kew Herbarium (K) for the possibility to examine collections previously deposited by R. Urtiaga at IMI.

\section{References}

Barreto RW, Evans HC. 1995 - The mycobiota of the weed Mikania micrantha in southern Brazil with particular reference to fungal pathogens for biological control. Mycological Research 99, 343352.

Braun U. 1993 - New genera of phytopathogenic deuteromycetes. Cryptogamic Botany 4, 107-114.

Braun U. 1995 - A monograph of Cercosporella, Ramularia and allied genera (phytopathogenic hyphomycetes). Vol. 1. IHW-Verlag Eching.

Braun U. 1999 - Taxonomic notes on some species of the Cercospora complex (VI). Cryptogamie, Mycologie 20, 155-177.

Braun U, Crous PW. 2007 - The diversity of cercosporoid hyphomycetes - new species, combinations, names and nomenclatural clarifications. Fungal Diversity 26, 55-72.

Braun U, Freire FCO. 2002 - Some cercosporoid hyphomycetes from Brazil - II. Cryptogamie, Mycologie 23, 295-328.

Braun U, Freire FCO. 2004 - Some cercosporoid hyphomycetes from Brazil - III. Cryptogamie, Mycologie 25, 221-244.

Braun U, Urtiaga R. 2008 - New species and 
new records of cercosporoid Hyphomycetes from Venezuela. Feddes Repertorum 119, 484-506.

Braun U, Mouchacca J, McKenzie EHC. 1999 - Cercosporoid hyphomycetes from New Caledonia and some other South Pacific islands. New Zealand Journal of Botany 37, 297-327.

Braun U, Crous PW, Kamal. 2003 - New species of Pseudocercospora, Pseudocercosporella, Ramularia and Stenella (cercosporoid hyphomycetes). Mycological Progress 2, 197-208.

Braun U, Hill F, Schubert K. 2006 - New species and new records of biotrophic micromycetes from Australia, Fiji, New Zealand and Thailand. Fungal Diversity 22, 13-35.

Braun U, Freire FCO, Urtiaga R. 2010 - New species and new records of cercosporoid hyphomycetes from Brazil, New Zealand and Venezuela. Polish Botanical Journal 55, 281-291.

Chupp C. 1934 - Cercosporae. In: Mycological explorations of Venezuela (eds Chardon LE, Toro RA). Monographs of the University of Puerto Rico, Series B, 2, 241-255.

Chupp C. 1954 - A monograph of the fungus genus Cercospora. Ithaca.

Crous PW, Braun U. 1996 - Cercosporoid fungi from South Africa. Mycotaxon 57, 233-321.

Crous PW, Braun U. 2003 - Mycosphaerella and its anamorphs: 1 . Names published in Cercospora and Passalora. CBS Biodiversity Series 1: 1-569.

Crous PW, Câmara MPS. 1998 - Cercosporoid fungi from Brazil. 2. Mycotaxon 68, 299-310.

Crous PW, Alfenas AC, Barreto RW. 1997 Cercosporoid fungi from Brazil. 1. Mycotaxon 64, 405-430.

Crous PW, Benchimol RL, Albuquerque FC, Alfenas AC. 2000 - Foliicolous anamorphs of Mycosphaerella from South America. Sydowia 52, 78-91.

Deighton FC. 1967 - Studies on Cercospora and allied genera. II. Passalora, Cercosporidium and some species of Fusicladium on Euphorbia. Mycological Papers 112, 1-80.
Deighton FC. 1973 - Studies on Cercospora and allied genera. IV. Cercosporella Sacc., Pseudocercosporella gen. nov. and Pseudocercosporidium gen. nov. Mycological Papers 133, 1-62.

Deighton FC. 1974 - Studies on Cercospora and allied genera. V. Mycovellosiella Rangel, and a new species of Ramulariopsis. Mycological Papers 137, 1-75.

Deighton FC. 1976 - Studies on Cercospora and allied genera. VI. Pseudocercospora Speg., Pantospora Cif. and Cercoseptoria Petr. Mycological Papers 140, $1-168$.

Deighton FC. 1979 - Studies on Cercospora and allied genera. VII. New species and redispositions. Mycological Papers 144, $1-56$.

Deighton FC. 1983 - Studies on Cercospora and allied genera. VIII. Further notes on Cercoseptoria and some new species and redispositions. Mycological Papers 151, $1-13$

Dianese JC, Furlanetto C, Santos LTP 1999 Pseudocercospora zeyheriae, a new combination for Cercospora zeyrae. Mycological Research 103, 40-42.

Doyle JJ, Chappill JA, Bailey CD, Kajita T 2000 - Towards a comprehensive phylogeny of legumes: evidence from RBCL sequences and non-molecular data. In: Advances in Legume Systematics (eds. Herendeen PS, Bruneau A). Royal Botanic Gardens, Kew 1-20.

Ellis MB. 1976 - More Dematiaceous Hyphomycetes. CAB, Kew.

García CE, Pons N, de Rojas CB. 1996 Cercospora y hongos similares sobre especies de Ipomoea. Fitopatología Venezolana 9, 22-36.

Guo YL, Hsieh WH. 1995 - The genus Pseudocercospora in China. Mycosystema Monographicum Series 2, 1-388.

Gupta BK, Kamal. 1987 - Some new species of Pseudocercospora from India. In: Perspectives in Mycological Research I, Prof. G.P. Agarwal Festschrift Volume (eds. Hasija BK, Rajak RC, Singh SM). New Delhi 19-33.

Hsieh WH, Goh TK. 1990 - Cercospora and Similar Fungi from Taiwan. Taipei. 
Inácio CA, Dianese JC. 1998 - Some foliicolous fungi on Tabebuia species. Mycological Research 102, 695-708.

Inácio CA, Dianese JC. 2006 - Foliicolous fungi on Tabebuia species from the cerado. Mycological Progress 5, 120127.

Kamal. 2010 - Cercosporoid Fungi of India. Bishen Singh Mahenda Pal Singh, Dehra Dun.

Kamal, Singh RP. 1980 - Fungi of Gorakhpur. XIX. Pseudocercospora. Sydowia 33, 157-161.

Kamal, Narayan P, Verma RP. 1986 - Fungi from hilly tracts of Uttar Pradesh - II. Indian Phytopathology 39, 453-458.

Kirschner R, Piepenbring M. 2006 - New species and records of cercosporoid hyphomycetes from Panama. Mycological Progress 5, 207-219.

Patil MS, Sawant RS. 1991 - Studies on Hyphomycetes - I. Indian Phytopathology 44(1), 15-20.

Pereira OL, Barreto R. 2005 - The mycobiota of the weed Mitracarpus hirtus in Minas Gerais (Brazil), with particular reference to fungal pathogens for biological control. Australasian Plant Pathology 34, 41-50.

Pereira OL, Barreto R. 2006 - Pseudocercospora palicoureae sp. nov. associated with the toxic rubiaceous weed Palicourea marcgravii in Brazil, with observations on its mycobiota. Fungal Diversity 23, 243-253.

Phengsintham P, Chukeatirote E, Abdelsalam K, Hyde KD, Braun U. 2010 - Cercospora and allied genera from Laos 2. Cryptogamie, Mycologie 31, 161-181.

Pons N. 1984 - Hyphomycetes de Venezuela. I. Mycovellosiella boldoae Pons sp. nov., M. brachycarpa (H. Syd.) Deighton y Phaeoramularia rauwolfiae Deighton. Ernstia 23, 17-26.

Pons N. 1988 - Ocurrencia de Cercospora aurantiae sobre Citrus spp. en Venezuela. Fitopatología Venezolana 1, 8-13.

Pons N. 1993 - Phaeoramularia ciccaronei sp. nov., hongo causante de la mancha en cadena en Sorghum spp. Fitopatología Venezolana 6, 2-7.

Pons N. 2004 - Especies de Pseudocercospora en colecciones micológicas de Carmen Emilia Benítez. Ernstia 14(1-4), 27-36.

Pons N. 2007 - Cercospora apii s. lat. en Venezuela. Revista de la Facultad de Agronomía de la Universidad del Zulia 24, 399-414.

Raghu Ram M, Mallaiah KV. 1993 - Pseudocercospora pongamiae-pinnatae sp. nov. from India. Mycological Research 97, 127-128.

Raghu Ram M, Mallaiah KV. 1996 - Three new and interesting species of Pseudocercospora from India. Mycotaxon 59, 349-357.

Rao HSG, Singh A, Kamal. 1995 - New species of Pseudocercospora associated with leaf spot in forest flora of India and Nepal. Indian Phytopathology 48, 254259.

Rao HSG, Narayan S, Bhartiya HD. 1996 Novel species of foliicolous hyphomycetes genus Pseudocercospora from Terai Belt of Northeastern Uttar Pradesh. Journal of the Living World 3(2), 20-29.

Schoch C, Shoemaker RA, Seifert KA, Hambleton S, Spatafora JW, Crous PW. 2006 - A multigene phylogeny of the Dothideomycetes using four nuclear loci. Mycologia 98, 1043-1054.

Shin HD, Kim JD. 2001 - Cercospora and allied genera from Korea. Plant Pathogens of Korea, Vol. 7, 1-302.

Soni KK, Dadwal VS, Jamaluddin. 1984 - A new species of Cercosporidium from India. Current Science 53, 877.

Sriskantha A, Sivanesan A. 1980 - A new Pseudocercospora from Sri Lanka. Transactions of the British Mycological Society 74, 431-433.

Viégas AP. 1945 - Alguns fungos do Brasil Cercosporae. Boletim de Sociedade Brasileira de Agronomia 8, 1-160.

Yen JM. 1975 - Les Cercospora de Cote d'Ivoire. - II. Bulletin Trimestrielle de la Société Mycologique de France 91, 89103.

Yen JM, Lim G. 1980 - Cercospora and allied genera of Singapore and the Malay Peninsula. Gardens' Bulletin, Singapore 33, 151-263.

Yen JM, Lim G. 1983 - Études sur les Champignons Parasites du Sud-Est 
Mycosphere Doi 10.5943/mycosphere/3/3/5

Asiatique, 47. Champignons Parasites de malaisie, 24. Bulletin Trimestrielle de la Société Mycologique de France 99, 357236.

Yen JM, Kar AK, Das BK. 1982a - Studies on Hyphomycetes from West Bengal, India,
II. Cercospora and allied genera of West Bengal, 2. Mycotaxon 16, 58-79.

Yen JM, Kar AK, Das BK. 1982b - Studies on Hyphomycetes from West Bengal, India, III. Cercospora and allied genera of West Bengal, 3. Mycotaxon 16, 80-95. 